\title{
Triassic pentadactyl tracks from the Los Menucos Group (Río Negro province, Patagonia Argentina): possible constraints on the autopodial posture of Gondwanan trackmakers
}

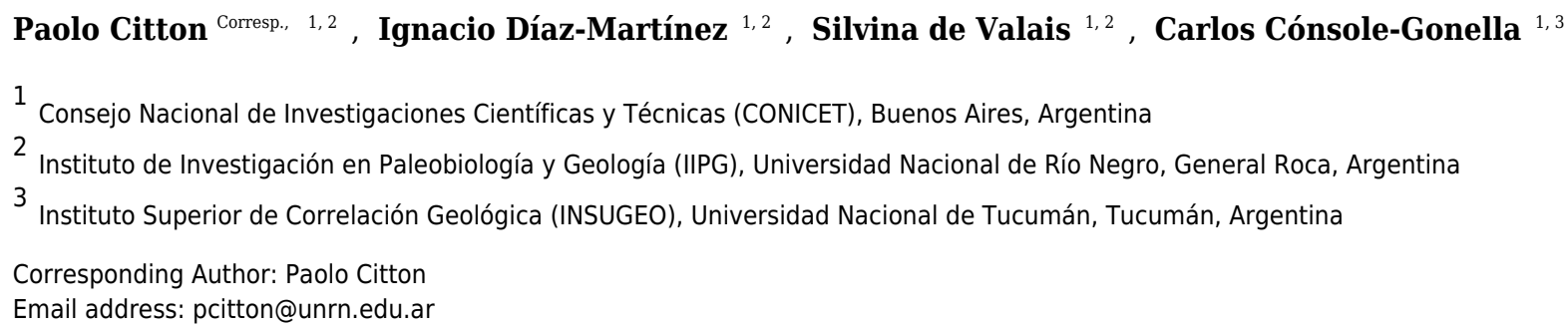

The Los Menucos locality in Patagonia, Argentina, bears a well-known ichnofauna mostly documented by small therapsid footprints. Within this ichnofauna, large pentadactyl footprints are also represented but to date were relatively underinvestigated. These footprints are here analyzed and discussed based on palaeobiological indications (i.e. trackmaker identification). High resolution digital photogrammetry method was performed to achieve a more objective representation of footprint three-dimensional morphologies. The footprints under study are compared with Pentasauropus from the Upper Triassic lower Elliot Formation (Stormberg Group) of the Karoo Basin (Lesotho, southern Africa). Some track features suggest a therapsid-grade synapsid as the potential trackmaker, to be sought among anomodont dicynodonts (probably Kannemeyeriiformes). While the interpretation of limb posture in the producer of Pentasauropus tracks from the Los Menucos locality agrees with those described from the dicynodont body fossil record, the autopodial posture does not completely. The relative distance between the impression of the digital (ungual) bases and the distal edge of the pad trace characterizing the studied tracks likely indicates a subunguligrade foot posture (i.e., standing on the last and penultimate phalanges) in static stance, but plantiportal (i.e., the whole foot skeleton and related soft tissues are weight-bearing) during the dynamics of locomotion. The reconstructed posture might have implied an arched configuration of the articulated metapodials and at least of the proximal phalanges, as well as little movement capabilities of the metapodials. Usually, a subunguligrade-plantiportal autopod has been described for gigantic animals (over six hundreds kilos of body weight) to obtain an efficient management of body weight. Nevertheless, this kind of autopod is described here for large but not gigantic animals, as the putative trackmakers of Pentasauropus were. This attribution implies that such an autopodial structure was promoted independently from the 
body size in the putative trackmakers. From an evolutionary point of view, subunguligradeplantiportal autopods not necessarily must be related with an increase in body size, but rather the increase in body size requires a subunguligrade or unguligrade, plantiportal foot. Chronostratigraphically, Pentasauropus was reported from Upper Triassic deposits of South Africa and United States, and from late Middle Triassic and Upper Triassic deposits of Argentina. Based on the stratigraphic distribution of the ichnogenus currently accepted, a Late Triassic age is here proposed for the Pentasauropus-bearing levels of the Los Menucos Group. 


\section{Triassic pentadactyl tracks from the Los Menucos Group}

2 (Río Negro province, Patagonia, Argentina): possible

\section{3 constraints on the autopodial posture of Gondwanan}

\section{4 trackmakers}

5 Paolo Citton ${ }^{1,2}$, Ignacio Díaz-Martínez ${ }^{1,2}$, Silvina de Valais ${ }^{1,2}$, Carlos Cónsole-Gonella ${ }^{1,3}$

$6 \quad{ }^{1}$ CONICET - Consejo Nacional de Investigaciones Científicas y Técnicas

7 22Instituto de Investigación en Paleobiología y Geología (IIPG), General Roca, Río Negro

8 province, Argentina

9 Instituto Superior de Correlación Geológica (INSUGEO), Miguel Lillo 205, Tucumán,

10 Argentina

11

12 Corresponding Author:

13 Paolo Citton

14 Av. Roca 1242, General Roca, Río Negro province, 8332, Argentina

15 Email address: pcitton@unrn.edu.ar

16

17 


\section{Abstract}

26 The Los Menucos locality in Patagonia, Argentina, bears a well-known ichnofauna mostly

27 documented by small therapsid footprints. Within this ichnofauna, large pentadactyl footprints

28 are also represented but to date were relatively underinvestigated. These footprints are here analyzed and discussed based on palaeobiological indications (i.e. trackmaker identification).

High resolution digital photogrammetry method was performed to achieve a more objective representation of footprint three-dimensional morphologies. The footprints under study are compared with Pentasauropus from the Upper Triassic lower Elliot Formation (Stormberg Group) of the Karoo Basin (Lesotho, southern Africa). Some track features suggest a therapsidgrade synapsid as the potential trackmaker, to be sought among anomodont dicynodonts (probably Kannemeyeriiformes). While the interpretation of limb posture in the producer of

Pentasauropus tracks from the Los Menucos locality agrees with those described from the dicynodont body fossil record, the autopodial posture does not completely. The relative distance between the impression of the digital (ungual) bases and the distal edge of the pad trace characterizing the studied tracks likely indicates a subunguligrade foot posture (i.e., standing on

40 the last and penultimate phalanges) in static stance, but plantiportal (i.e., the whole foot skeleton 41 and related soft tissues are weight-bearing) during the dynamics of locomotion. The

42 reconstructed posture might have implied an arched configuration of the articulated metapodials 43 and at least of the proximal phalanges, as well as little movement capabilities of the metapodials.

44 Usually, a subunguligrade-plantiportal autopod has been described for gigantic animals (over six 45 hundreds kilos of body weight) to obtain an efficient management of body weight. Nevertheless, 46 this kind of autopod is described here for large but not gigantic animals, as the putative 
47 trackmakers of Pentasauropus were. This attribution implies that such an autopodial structure

48 was promoted independently from the body size in the putative trackmakers. From an

49 evolutionary point of view, subunguligrade-plantiportal autopods not necessarily must be related

50 with an increase in body size, but rather the increase in body size requires a subunguligrade or

51 unguligrade, plantiportal foot. Chronostratigraphically, Pentasauropus was reported from Upper

52 Triassic deposits of South Africa and United States, and from late Middle Triassic and Upper

53 Triassic deposits of Argentina. Based on the stratigraphic distribution of the ichnogenus

54 currently accepted, a Late Triassic age is here proposed for the Pentasauropus-bearing levels of

55 the Los Menucos Group.

56

57

58

59

60

61

62

63

64

65

66

67

68

69

70

71 


\section{INTRODUCTION}

76 Tetrapod tracks are valuable fossils informing about anatomy (e.g., Carpenter, 1992), functional

77 adaptations (e.g., Baird, 1980), motion (e.g., Avanzini, Piñuela \& García-Ramos, 2011) and

78 ethology (e.g., Lockley et al., 2016) of extinct animals, greatly expanding the potential of

79 information that is often precluded from the body-fossil record. The detailed analysis of tetrapod

80 footprints is therefore significant for integrating and revising data derived from the tetrapod

81 body-fossil record.

82 The scientific study of tetrapod footprints in Argentina is relatively recent compared to

83 that of Europe (Duncan, 1831; Kaup, 1835a, b) and North America (Hitchcock, 1836), dating

84 back to the first half of the twentieth century (von Huene, 1931). One of the most important

85 contribution to tetrapod ichnology in Argentina is that of Casamiquela (1964), who devoted

86 himself to the study of Triassic and Jurassic tetrapod tracks from Patagonia. Later, other

87 contributions focused on important Triassic ichnofaunas from other regions of Argentina have

88 been published (e.g., Romer, 1966, Bonaparte, 1966; Leonardi, 1994; Melchor \& de Valais,

89 2006). Among the Triassic vertebrate ichnological record, the Los Menucos ichnofauna, which is

90 dominated by small therapsid footprints, was repeatedly studied (Casamiquela, 1964, 1975,

91 1987; Leonardi \& de Oliveira, 1990; Leonardi, 1994; Domnanovich \& Marsicano, 2006;

92 Melchor \& de Valais, 2006; de Valais, 2008; Domnanovich et al., 2008; Díaz-Martínez \& de

93 Valais, 2014). The bulk of this ichnofauna was originally attributed to different ichnotaxa by

94 Casamiquela $(1964,1975)$, but after the revision made by Melchor \& de Valais (2006), most of

95 the ichnogenera erected by Casamiquela have been considered as synonyms of Dicynodontipus. 
96 Moreover, an indetermined chirotheroid track (de Valais, 2008), a single track referred to as

97 Rhynchosauroides, and large pentadactyl footprints mentioned as Pentasauropus sp.

98 (Domnanovich et al., 2008) have also been reported from the Los Menucos area. From the same

99 locality, several slabs with pentadactyl tracks comparable to those described by Domnanovich et

100 al. (2008) were collected many years ago but remained unpublished until now.

101 An ichnological analysis based on this material is here proposed and discussed in terms

102 of the palaeobiology, identity and autopodial anatomy of the trackmaker. Besides, a brief

103 discussion of the chronostratigraphy of this record is provided.

104

105 INSTITUTIONAL ABBREVIATIONS

106 LES - Laboratoire de Paléontologie, Institut de Sciences de l'Evolution of the University of

107 Montpellier II collection, Montpellier, France; MPCA - Museo Provincial Carlos Ameghino,

108 Cipolletti, Río Negro province, Argentina; MMLM - Museo Municipal de Los Menucos, Los

109 Menucos, Río Negro province, Argentina; MMLM (ex MRPV) - Museo Provincial María Inés

110 Kopp, Valcheta, Río Negro province, Argentina.

111

112 MATERIAL AND METHODS

113 The present study is based on the direct examination of track-bearing slabs MPCA 27029-1 with

114 three pes-manus couples, two of which incomplete (concave epireliefs, i.e., negative relief),

115 MPCA 27029-2 with a single left pes-manus couple (convex hyporeliefs, i.e., positive relief),

116 MPCA 27029-3 with two pes-manus couples and an incomplete pes (convex hyporeliefs),

117 MPCA 27029-4 with a single pes-manus couple (convex hyporeliefs), MPCA 27029-5 with a

118 single track (convex hyporeliefs), MPCA 27029-9 with five pes-manus couples, three of which 
119 incomplete (convex hyporeliefs), MPCA 27029-16 with three pes-manus couples, one of which

120 incomplete, and five incomplete tracks (convex hyporeliefs), MPCA 27029-21 with two pes-

121 manus couples and four tracks (convex hyporeliefs), MPCA 27029-33 with two pes-manus

122 couples (convex hyporeliefs), MMLM 1 with two pes-manus couples(convex hyporeliefs),

123 MMLM 2 with two incomplete pes-manus couples (convex hyporeliefs), and MMLM 075-1 (ex

124 MRPV 1987P.V.06 in Domnanovich et al., 2008, hereafter MMLM 075-1) with two incomplete

125 pes-manus couples (concave epireliefs). Except for the specimen MMLM 075-1, the material

126 under study was to date unpublished. A few other slabs, both with and without label, are stored at

127 the MPCA but were not considered in this study due to poor preservation of the tracks. In total,

128 about 60 footprints were analyzed. For each slab, tracks were numbered using Arabic numerals

129 and, when referring to single tracks in the text, they are indicated as /number following the slab

130 label (e.g., MPCA 27029-1/4 where MPCA 27029-1 and number 4 indicate slab and single track,

131 respectively). The studied material mainly consists of isolated sets or incomplete trackways.

132 The provenance of the track-bearing slabs can be traced back to the Felipe Curuil ex

133 quarry, Yancaqueo farm, east of the town of Los Menucos (Domnanovich et al., 2008), but the

134 exact stratigraphic repositioning of the material is currently prevented and inherent data are

135 lacking in the literature.

136 Microfacies characterization

137 Two thin sections were obtained from the slab MPCA 27029-19 (its footprints are poorly

138 preserved and not included in this study), both parallel and perpendicular to the trampled surface.

139 For the description of the thin sections, Mackenzie, Donaldson \& Guilford (1982), and Scasso \&

140 Limarino (1997) were taken as a reference. Thin sections are presently stored at the MPCA and

141 labelled as MPCA 27029/19.1 (parallel to the trampled surface) and MPCA 27029/19.2 
142 (perpendicular to the trampled surface).

\section{Measurements}

144 Measurements related to trackmaker body dimension were obtained from slabs MPCA 27029-1,

145 MPCA 27029-9, MPCA 27029-16 and MPCA 27029-21. From single tracks, which are mainly

146 represented by digit traces, measurements of footprint width were taken. Also, track features and

147 differential depth of impressions in some cases allowed to recognize the footprint identity, the

148 side of the trackway when incompletely preserved, or tracks belonging to different trackways

149 (e.g., MMLM 075-1), and element orientations. Track measurements were performed according

150 to guidelines introduced by Leonardi (1987). Track outlines were represented through

151 interpretive drawings.

\section{Digital models}

153 High-resolution digital photogrammetry was undertaken to achieve a more objective

154 representation of track three-dimensional morphology, according to a recently described standard 155 protocol for ichnological studies (Falkingham et al., 2018). To model the studied specimens, the

156 software package Agisoft PhotoScan Pro (Educational License), which enables creating 3D

157 textured meshes by means of semi-automatic processing of images (Mallison \& Wings, 2014), 158 was used.

159 The images selected for the photogrammetric process were acquired using a Nikon

160 Coolpix P520 camera with 4.3-7.6 focal length, resolution 4896x3672 and pixel size ranging

161 from $1.25 \times 1.25 \mu \mathrm{m}$ and $1.27 \times 1.27 \mu \mathrm{m}$. Main processing parameters are reported in Table 1 . In

162 order to correctly scale the calculated model, a metric reference marker was applied on the

163 surface. Three-dimensional models were converted to colour topographic profiles using the

164 software Paraview (version 5.4.1). 


\section{GEOLOGICAL SETTING}

167 Continental deposits of Triassic age in Argentina were accumulated in different basins in western 168 and northwestern regions (Mendoza, San Juan, San Luis and La Rioja provinces) as well as in

169 Patagonia (northern sector of the Santa Cruz province and Río Negro provinces). These

170 elongated, narrow rift basins with prevalent NW-SE and NNW-SSE trends were developed

171 during Permian and Triassic periods and are related with the breakup of the western margin of

172 south-west Gondwana (Kokogian et al., 1999; Franzese \& Spalletti, 2001; Barredo et al., 2012).

173 The Triassic tetrapod track record of southern South America is exclusive to three basins,

174 namely the Ischigualasto-Villa Unión Basin (San Juan and La Rioja provinces), the Cuyo Basin

175 (Mendoza and San Juan provinces) and the Los Menucos basin (Río Negro province) (e.g.,

176 Melchor, Genise \& Poiré, 2001; Melchor \& de Valais, 2006; de Valais, 2008 and references

177 therein). According to Spalletti (1999), in the northern basins (i.e. Ischigualasto-Villa Unión and

178 Cuyo) the sedimentation encompasses the Lower to Upper Triassic, while in the Los Menucos

179 Basin the sedimentation took place in the Late Triassic, based on the age of volcanic activity in

180 north-central Patagonia.

181 After the works of Stipanicic (1967), Stipanicic et al. (1968) and Stipanicic \& Methol

182 (1972, 1980), the Los Menucos Group (also as ‘Complejo Los Menucos' - Los Menucos

183 Complex sensu Cucchi, Busteros \& Lema, 2001) was established by Labudía \& Bjerg (2001) to

184 indicate dacitic to rhyolitic ignimbrites, mesosilicic lavas and subordinate Triassic sedimentary 185 rocks exposed around Los Menucos town, in the north-western sector of the North Patagonian 186 Massif (Río Negro province, Argentina; Fig. 1A). 
Within the Los Menucos Group, two lithostratigraphic units were defined, namely the

188 Vera Formation at the base and the Sierra Colorada Formation on top (Labudía \& Bjerg, 2001,

189 2005, and references therein; Fig. 1B). The Vera Formation, from which tetrapod tracks are

190 historically reported, is mainly composed of volcanic and continental deposits laid down inside

191 small basins bordered by regional and local faults with strike NE-SW, E-W and NW-SE

192 (Labudía \& Bjerg, 2001, 2005). The Vera Formation is mainly represented by brownish to

193 yellowish conglomerates, white to greenish sandstones and reddish brown to red pelites, with

194 which volcanic ashes, tuffs and tuffites, dacitic pyroclastic flow products and volcanic breccias

195 are intercalated (Labudía \& Bjerg, 2001, 2005). Sedimentation took place mainly in alluvial

196 plain, floodplain, ephemeral river and small lacustrine palaeoenvironments (Labudía \& Bjerg,

197 2005), under seasonal climate condition with alternating periods of dry and wet conditions

198 (Gallego, 2010). Sedimentary and volcaniclastic levels within the Vera Formation are

199 characterized by a very rich palaeoflora, the so-called "Dicroidium-type flora" (Stipanicic, 1967;

200 Stipanicic \& Methol, 1972; Artabe, 1985a, b; Labudía et al., 1995; Labudía \& Bjerg, 2001, 2005)

201 and by an abundant tetrapod ichnofauna, preserved on sandstones with poorly sorted grains and

202 with a variable content of tuffaceous breccias (Melchor \& de Valais, 2006). Finds of skeletal

203 fauna are scarce and are so only represented by remains of an amiiform fish (Bogan, Taverne \&

204 Agnolin, 2013).

205

The Sierra Colorada Formation is essentially made of ignimbritic volcanic rocks (Labudía

\& Bjerg, 2001, 2005), dated at $222 \pm 2 \mathrm{Ma}$ with the $\mathrm{Rb} / \mathrm{Sr}$ isochron method (Norian, Late

207 Triassic; Rapela et al., 1996) and at 206.9 \pm 1.2 Ma with the Ar/Ar method (Rhaetian, Late

208 Triassic; Lema et al., 2008). These datations do not radiometrically constrain the base of the 
209 Vera Formation, for which a Late Triassic age was historically proposed on the basis of the

210 "Dicroidium-type flora" and the tetrapod ichnofauna.

211 More recent results indicated an age of $257 \pm 2 \mathrm{Ma}$ (Wuchiapingian, Late Permian) for a

212 rhyolitic ignimbrite, $252 \pm 2 \mathrm{Ma}$ (Changhsingian, Late Permian) for an andesite, and $248 \pm 2 \mathrm{Ma}$

213 (Olenekian, Early Triassic) for a dacitic ignimbrite (Luppo et al., 2017) of the Los Menucos

214 Group. These new data predate the main volcanic activity to an about a 10 Ma period between

215 the Late Permian and the Early Triassic, making the lower part of the Los Menucos Group

216 coeval with the La Esperanza Plutono-Volcanic Complex (Gonzalez et al., 2017; Luppo et al.,

217 2017).

\section{Sedimentological observations}

219 Track-bearing slabs consist of yellowish to greenish, medium to mainly coarse grained and 220 poorly sorted volcaniclastic sandstone lacking of sedimentary structures in hand samples, neither

221 on the surface or cross-section.

222 The observed texture ranges from inequigranular/equigranular (Figs. 2A, 2B) to

223 predominantly equigranular (Fig. 2C). Phenocrysts, mainly subhedral and anhedral, range in

224 dimension from $0.5 \mathrm{~mm}$ to $1.5 \mathrm{~mm}$ and show in one case incipient orientation. Phenocrysts are

225 represented mainly by plagioclase, quartz, alkaline feldspar, biotite, amphibole (hornblende),

226 orthopyroxene (enstatite) and calcite floating in a mafic, glassy matrix.

227 The dominant epiclastic texture observed at the base of the trampled surface (thin section

228 MPCA 27029/19.2), mainly represented by fragments of quartz and some lithics displaying

229 attrition and rounded to sub-angular shape, suggesting sedimentary reworking of an original tuff

230 of probable dacitic composition. The texture observed in the thin section MPCA 27029/19.1

231 instead indicates a limited sedimentary reworking (Fig. 2D). In section, a faint normal gradation 
232 can be observed most likely indicating short sedimentation events; on the whole, the track-

233 bearing slabs can be related to a proximal fluvial environment

234

235 TRACK RECORD

236 Track preservation

237 Specimen MMLM 075-1 is composed of four slabs, two as negative (concave) relief, labeled as 238 MMLM 075-1/1a, /2 and /3a, and two as their positive (convex) filling, labeled as MMLM 075-

$2391 / 1 \mathrm{~b}$ and $3 / \mathrm{b}$. There are no evidences of any layer between the concave and the convex reliefs

240 and the shape of both concave epireliefs and convex hyporeliefs are exactly complementary (Fig.

241 3). Therefore, and taking into account that the tracks preserved similarly (i.e. sub-circular/sub-

242 ovoidal to pointed digit impressions; roughly sub-circular to elliptical pad tracks; very thin

243 displacement rims in the pad and well-marked in the digit impressions; Figs. 4-9), in our opinion

244 the concave epireliefs are true tracks (sensu Marty, Falkingham \& Richter, 2016) and the convex

245 hyporeliefs are their natural casts (sensu Marty, Falkingham \& Richter, 2016).

246 In general, the tracks studied here are moderately well preserved (grade 1 sensu

247 Belvedere \& Farlow, 2016), and the true tracks are not elite tracks (sensu Lockley, 1991). In

248 addition, they are not modified true tracks (sensu Marty, Falkingham \& Richter, 2016) because

249 they lack evidence of physiochemical (e.g., weathering) and/or biological influences after they

250 were made. Thereby, the shape of these tracks is mainly conditioned by the substrate consistency

251 (grain size and water content). Recently, Falk et al. (2017) performed neoichnological

252 experiments that compared the shape of tracks impressed in three different sediments (fine,

253 medium and coarse sand) with different moisture contents (wet, moist and dry). They concluded

254 that wet and dry coarse sediments preserve tracks without fine details, but moisture coarse 
255 sediment might preserve the overall track shape and details as claw impessions. As has been

256 previously commented, the tracking surface is a medium to coarse sandstone, and tracks have

257 depth digit impressions with extruded rims.

258 Therefore, and according to the Falk et al. (2017) experiments, the trackmakers most

259 likely walked on humid, not waterlogged nor dry, coarse sediments with a moderately plastic

260 behaviour, able to record the main anatomical features of the autopods.

\section{Track description}

262 The material are manus and pes tracks with very low dimensional heteropody (i.e. condition in

263 which the autopods are dimensionally and morphologically different), mainly preserved as

264 tetradactyl impressions, although pentadactyl tracks are also present (MPCA 27029-1/4/6,

265 MPCA 27029-2/2, MPCA 27029-4/2, MPCA 27029-16/10, MPCA 27029-33/2, MMLM 075-1)

266 (Figs. 4, 5E-5H, 7A-7D, 8), as well as tridactyl ones displaying only the central digits (MPCA

267 27029-9/2, MPCA 27029-16/8, MPCA 27029-21/3, MMLM 1/1, MMLM 2/3) (Figs. 6G-6H, 7,

268 9). Morphologically, manus and pes tracks are strongly symmetrical. Digit traces are commonly

269 arranged to shape an arcuate pattern that is convex anteriorly, according to which the digit III

270 trace (the central one) or digit III and IV traces are the most projecting. Variability affecting the

271 number of digits can occur on the same slab (e.g., MPCA 27029-21, MMLM 2; Figs. 7E-7H, 9E-

$2729 \mathrm{H})$. In the material under study the degree of curvature of the arcuate pattern is variable and

273 appears more pronounced in some smaller tracks (e.g., MPCA 27029-16/7/9/10; Figs. 7A-7D)

274 than in larger ones (e.g., MPCA 27029-1/4, MMLM 075-1, MMLM 2/2; Figs. 4, 8E-8H, 9E-9H).

275 In the smaller tracks (e.g., MPCA27029-16, interpreted as left by a juvenile individual), the

276 morphology of digit traces, their relative spacing and orientation, as well as the position of pes

277 and manus impression is comparable with that of the larger tracks. When present, also the sole 
278 pad trace resembles that observed in the footprints of larger dimension. Thus, apart from the

279 degree of curvature, the general morphology remains consistent despite dimensional differences 280 (see Figs. 4A-4D and 7A-7D).

281 Digit traces can be characterized by a sub-circular/sub-ovoidal morphology (e.g., MPCA 282 27029-9, MPCA 27029-16, MPCA 27029-21; Figs. 6E-6H, 7), while in other cases they are 283 markedly pointed (e.g., MPCA 27029-2, MPCA 27029-4, MPCA 27029-5, MPCA 27029-33;

284 Figs. 4E-4H, 5E-5H, 6A-6D, 8A-8D). These two morphologies can co-exist on the same slab and 285 within the same set or trackway, thus pertaining to the spectrum of internal variability of the 286 material under study. When pointed, the most medial digit traces (i.e. digit I or II imprints and, to 287 a lesser extent, digit III and IV imprints), both of manus and pes tracks, can be affected by drag 288 marks. These extramorphological features (see Peabody, 1948) qualitatively range from weakly 289 hinted and short (e.g., MPCA 27029-1/6, MPCA 27029-2/1, MPCA 27029-3/1/2, MPCA 27029290 4/2, MPCA 27029-5, MPCA 27029-9/4/6; Figs. 4, 5, 6) to highly sharp and long (e.g., MMLM 291 075-1, MMLM 1 and MMLM 2; Figs. 8E-8H, 9A-9D).

292 Central digits are commonly the most deeply and uniformly impressed, both in manus 293 and pes tracks (e.g., MPCA 27029-4, MPCA 27029-5, MMLM 1; Figs. 5F-5G, 6B-6C, 9B-9C). 294 When a certain degree of variability is observed, digit III and IV imprints are the most deeply 295 imprinted (e.g., MPCA 27029-1, MPCA 27029-3, MPCA 27029-16; Figs. 4B-4C, 5B-5C, 7B296 7C), followed by digit II and I imprints. The digit V trace, when preserved, is shorter and closer 297 to the pad trace than the other digit traces and is only faintly imprinted (e.g., MMLM 075-1, 298 Figs. 8E-8H; but see MPCA 27029-16/9/10 for a different configuration of the digit depth of 299 impression, most likely due to the reaction of the substrate and water content of the sediments at 300 the time of impression, Figs. 7B-7C). 
Behind the digit traces, a roughly sub-circular to elliptical sole pad trace can be preserved

302

303

304

305

306

307

308

309

310

311

312

313

314

315

316

317

318

319

320

321

322

323

(e.g., MPCA 27029-1/2/4/5/6, MPCA 27029-5, MPCA 27029-16/10, MMLM 075-1, MMLM

1/2/4, MMLM 2/1; Figs. 4A-4D, 6A-6D, 7A-7D, 8E-8H, 9). The sole pad trace lies at a short distance from the base of the central digit traces and commonly approximates the most medial and lateral digit imprints (e.g., MPCA 27029-1; Figs. 4A-4D). Commonly, the sole pad trace is separated from central digit traces ahead by a non-impressed area, which appears as a groove or as a ridge depending on the mode of preservation, tapering towards the most medial and lateral digit imprints. This should not be confused with displacement areas of similar morphology, which are instead related to digit traces (i.e. thrust of digit pushing the sediment backwardly; Fig. 10), where this area is not impressed (e.g., MPCA 27029-2, MPCA 27029-3/1/4, MPCA 270294, MPCA 27029-9/3/5, MPCA 27029-21/4, MPCA 27029-33/1/2/3, MMLM 2/3; Figs. 4E-4H, 5, 6E-6H, 7E-7H, 8A-8D, 9E-9H).

The sole pad trace is more deeply impressed in its central portion; depth of impression slightly decreases toward the lateral and distal portion (i.e. close to the non-impressed area behind digit traces, MPCA 27029-1, MMLM 075-1, MMLM 1; Figs. 4B-4C, 8F-8G, 9B-9C). When possible, we tried to define the orientation of the footprint axis with respect to the trackway midline. The axis of pes tracks is in some cases rotated inwardly with respect to the trackway midline but it can also be parallel to the trackway midline (e.g., MPCA 27029-9, 27029-16), while manus tracks show a wider range of variability, being both inwardly and outwardly rotated with respect to the hypothetical trackway midline (e.g., MPCA 27029-1 and MMLM2, respectively). When possible, measurements and ratios were taken; measurements were performed taking into account digit III as the homologous point, both for manus and pes tracks. Results are reported in Table 2 and Table 3. In general, footprint are wider than long with 
324 oblique pace length ranging between $60 \%$ and $80 \%$ of the stride length. Pace angulation ranges

325 from $70^{\circ}$ to $101^{\circ}$. Gleno acetabular distances, measured considering an amble gait (other gait are

326 reported in Table 2), indicate trackmakers with trunk length approximately of $37.4 \mathrm{~cm}$ (MPCA

327 27029-16), $63.1 \mathrm{~cm}$ (MPCA 27029-9) and $91.6 \mathrm{~cm}$ (MPCA 27029-1). The proximal margin of

328 the digit traces lies at less than $3 \mathrm{~cm}$ from the distal margin of the sole trace (Table 3 ).

329 Remarks. The footprints from the Los Menucos ichnosite are characterized by having the

330 following features: homopodic manus and pes tracks with low dimensional heteropody, up to

331 five digit imprints aligned, forming an anteriorly convex arch, a sole pad trace more impressed

332 centrally or centro-laterally. On the basis of these general features, the specimens from Los

333 Menucos are tentatively referred to as Pentasauropus.

334 The ichnogenus Pentasauropus Ellenberger, 1970 was established on the basis of

335 material collected and described some years before (Ellenberger, 1955) from the Upper Triassic

336 lower Elliot Formation (Stormberg Group) of the Karoo Basin of Lesotho (Southern Africa).

337 Five ichnospecies were originally included in the ichnogenus, namely Pentasauropus erectus,

338 Pentasauropus incredibilis, Pentasauropus maphutsengi, Pentasauropus morobongensis and

339 Pentasauropus motlejoi, which remained unchanged in the subsequent formal listing

340 (Ellenberger, 1970, 1972). Material from the Ellenberger collection referred to this ichnogenus is

341 housed at the University of Montpellier (France) and represented by six casts originally

342 mentioned as Pentasauropus incredibilis (LES 054 1-3, LES 054 4), Pentasauropus

343 morobongensis (LES 005) Tetrasauropus gigas (LES 038), plus some missing specimens (see

344 D'Orazi Porchetti \& Nicosia, 2007, and reference therein for a complete assessment of inventory 345 numbers). 
After the original and subsequent publications of Ellenberger $(1955,1970,1972)$, the

347 ichnogenus was considered as valid by Olsen \& Galton (1984), Lockley \& Meyer (2000),

348 D’Orazi Porchetti \& Nicosia (2007), Bordy, Abrahams \& Sciscio (2017), and Hunt, Lucas \&

349 Klein (2018). D’Orazi Porchetti \& Nicosia (2007) emended the diagnosis of the ichnogenus to

350 appoint the type ichnospecies and considered the five ichnospecies as synonyms of

351 Pentasauropus incredibilis. Differences in track pattern were considered as originated by

352 dimensional constraints and/or behavioural factors, and the main footprint characteristics (e.g.,

353 number and arrangement of digits, heteropody) do not justify an ichnospecies separation

354 (D’Orazi Porchetti \& Nicosia, 2007). Moreover, agreeing with Lockley \& Meyer (2000), the

355 same authors assigned tracks originally referred to as Tetrasauropus gigas to Pentasauropus.

356 In agreement with the emended ichnogeneric diagnosis by D’Orazi Porchetti \& Nicosia

357 (2007), the arcuate pattern of manus and pes tracks derived from the five equally spaced claw or

358 ungual traces (those of imprints of digit II, III and IV are the largest). In other cases a roughly

359 rounded sole pad is observed behind claw or ungual traces (LES 053 A, B, C in Ellenberger,

360 1972, pl. IV and V, and LES 038). According to D'Orazi Porchetti \& Nicosia (2007), the axis of

361 the pes impressions is always inwardly rotated, while that of the manus impression can range

362 from slightly inwardly rotated (LES 052 B and LES 053 A) to slightly outwardly rotated (LES

363038 and LES 052 A). Although long and complete trackways are not represented, this feature

364 seems to characterize also the studied material based on the reconstruction of an hypothetical

365 midline (e.g., Fig. 4A-D, footprints 4 and 6; Fig. 5A-D, footprint 2). In some cases (e.g., MPCA

366 27029-9 and MPCA 27029-21, Table 2) short stride length in relation to overall footprint

367 dimension could indicate a primary overstepping. However, in our opinion this trackway

368 characteristic cannot be ensured on the basis of the material under study and most probably, 
369 taking into account the complexity of the dynamic of locomotion, cannot be inferred only from

370 the stride lengths and footprint dimensions. Thus, for the time being, we prefer not to stress the

371 interpretation about the overstepping. Additionally, overprinting in the studied material is absent;

372 in some cases (e.g. MPCA 27029-3 and MPCA 27029-33, Figs. 5B, 8B) interferences indicate

373 that the hind print in the set was left after the fore print. For these cases, overstepping is not

374 sustainable.

375 Outside of the Southern Africa, tracks tentatively referred to the ichnogenus were reported

376 from Upper Triassic Chinle Group of Utah (Lockley \& Hunt, 1995; Hunt-Foster et al., 2016) and

377 Colorado (Gaston et al., 2003, fig. 12B), both USA. Moreover, tracks possibly referable to

378 Pentasauropus were found in the Gettysburg Shale of the Gettysburg Basin of the Newark

379 Supergroup (Baird pers. comm in Olsen \& Galton, 1984). In Argentina, apart from the report from

380 the Triassic Vera Formation (Río Negro province, Domnanovich et al., 2008), tracks referred to as

381 Pentasauropus were described from the Carnian Portezuelo Formation ('Type Q2' sensu

382 Marsicano \& Barredo, 2004). In addition, tracks with similar morphology to Pentasauropus were

383 also reported from the Middle Triassic Cerro de Las Cabras Formation (Mendoza province, as cf.

384 Pentasauropus in de Valais, Melchor \& Bellosi, 2006) and from the Portezuelo Formation (San

385 Juan province) as 'huellas cuadrúpedas tipo C' (i.e., quadrupedal tracks type C; de Valais, 2008)

386 but, for the time being, this material remains in open nomenclature.

\section{Zoological attribution}

388 Several attempts to identify the trackmaker of Pentasauropus have been made. The ichnogenus

389 was originally attributed to amphibians, basal melanorosaurid, ornithischian, anapsid and basal

390 sauropod (Ellenberger \& Ellenberger, 1958: p. 67; Ellenberger, 1970, 1972). Moreover, Haubold

391 (1974, 1984) referred Pentasauropus to a sauropod or therapsid trackmaker. A dicynodont was 
392 also proposed as producer by Olsen \& Galton (1984), Anderson, Anderson \& Cruickshank

393 (1998) and Lockley \& Meyer (2000). Galton \& Heerden (1998) attributed Pentasauropus to

394 large anomodont dicynodonts. D’Orazi Porchetti \& Nicosia (2007) accepted the attribution to a

395 dicynodont, observing a good match between the skeletal autopodia of Triassic dicynodonts and

396 the structure of digital impressions of the manus and pes, apart from the strong homopody and

397 the limb posture (see also Walter, 1986). Recently, the kannemeyeriiform dicynodont

398 Pentasaurus goggai from the lower Elliot Formation of South Africa has been referred as

399 probable trackmaker of Pentasauropus tracks from the same lithostratigraphic unit (Kammerer, 400 2018).

401 The studied material from the Los Menucos locality presents some features that allow

402 corroboration of the therapsid interpretations about trackmaker identity. At the same time,

403 constraining the identity of the putative trackmaker opens the way for new inferences about the

404 posture of the autopodia.

405 Limb posture kept by Pentasauropus trackmakers during the step cycle can be tentatively

406 inferred from the trackway pattern (Peabody, 1948, 1959; Kubo \& Benton, 2009; Kubo \& Ozaki, 407 2009), even if this interpretation is often far from being simple and linear (Crompton \& Jenkins,

408 1973). For example, it must be noted that non therapsid-synapsids with sprawling posture could

409 have left trackways in which the left and right tracks lie near to the axial midline (i.e., narrow

410 internal trackway width mirroring a semi-erect to erect posture of the trackmaker) by adopting

411 side to side flexion of the trunk (Hopson, 2015). The same was described for a therapsid

412 trackway by Smith (1993). Some degree of lateral undulation of the vertebral column causing

413 swing of the hips has been also described on the basis of skeletal remains (Fröbisch, 2006: p.

414 1305). However, in sprawling trackmakers adopting trunk flexion and producing narrow 
415 trackways, tracks are mainly inwardly oriented with respect to the trackway midline (see

416 Hopson, 2015: fig. 8.1). In the studied material, the orientation of footprint axis (passing through

417 digit III) is parallel to the travel direction. This feature, combined with the extremely narrow

418 internal trackway width measured from pes tracks (see Table 2 and Figs. 4A-4D, 5A-5D, 6E-6H,

419 7A-7D), allow to exclude a sprawling posture and most likely indicate a semi-erect posture for

420 the trackmaker hind limbs. A lateral trunk undulation during the step cycle could have been also

421 adopted by the Pentasauropus trackmaker and it would account for the variable pace angulation

422 measured in manus tracks, possibly coupled with low trackmaker velocity.

423 A more upright posture with respect to that of non-therapsid synapsids is also indirectly

424 sustained by the symmetry of manus and pes tracks. This feature mirrors a symmetry of the

425 trackmaker's autopods, a feature combined with the acquisition of upright posture and limbs

426 parallel to the sagittal plane of the trackmaker during locomotion (Romer, 1956; Hopson, 1995).

427 Number of digit imprints, symmetry of manus and pes track, and the morphology of

428 unguals enable us to corroborate previous interpretations and suggest a dicynodont as the most

429 probable trackmaker of Pentasauropus. Also the limb posture as supposed from tracks

430 sufficiently matches those discussed for Triassic dicynodonts by Fröbisch (2006).

431 Pentasauropus producers, based on the type specimens, were characterized by a very low

432 dimensional heteropody and morphological homopody. Thus, mainly based on these characters,

433 a quite confident match can be found, among dicynodonts, with Kannemeyeriiformes [see, for

434 example, the descriptions and reconstructions of the autopods of Dinodontosaurus by Morato

435 (2006: fig. 30), Tetragonias njalilus by Cruickshank (1967: fig. 17) and by Fröbisch (2006: fig.

436 9)]. Kannemeyeriiform manual and pedal skeletal elements are in fact generally homomorphic

437 and conservative into the clade, as recently stated by Kammerer (2018). Variation in manus 
438 morphology among kannemeyeriiforms is only limited to minor differences in ungual shape

439 (Lucas, 2002). Digit traces are here considered roughly compatible with broad ungual phalanges

440 characterized by rounded tips but the exact shape cannot be determined. The morphological

441 variability of ungual traces most likely relates to substrate conditions at the time of impression

442 and, as discussed below, from the dynamics of the locomotion of the producers.

Among the other possible producers already mentioned in the literature, are excluded: i)

444 an amphibian trackmaker, because of the pentadactyl manus and general morphology; ii) an

anapsid trackmaker, for the trackway configuration and footprint axis orientation; iii) a

446 sauropodomorph and sauropod trackmaker, for the trackway configuration, footprint axis

447 orientation and morphological homopody.

448 The posture of the autopodia of the Pentasauropus trackmaker that can be inferred from

449 the ichnological material differs from that inferable from the description by Cruickshank (1967).

450 In those Pentasauropus tracks that show an impression of the sole or palm, a negligible distance

451 between the distal margin of the sole/palm pad trace and the proximal margin of the central digit

452 traces, further reducing towards digits I and V, was observed (Table 3). This feature most likely

453 indicates that not all of the foot bones contacted the ground during locomotion, at the same time

454 constraining the orientation of metapodial and basipodial elements, and also that of the more

455 proximal phalanges, in the articulated autopod. Thus, the reconstruction proposed here

456 contemplates an inclined position of pedal and manual elements in the autopods of

457 Pentasauropus producers. The sub-circular to elliptical pad trace behind the digit traces is

458 consequently considered compatible with an extended fleshy pad below the basipodials and

459 likely metapodials of the autopods of the producer (Fig. 11). 


\section{DISCUSSION}

\section{The autopod posture of Pentasauropus trackmaker}

463 Compared to the ichnogenus Pentasauropus, tracks from Los Menucos Group have allowed us to

464 verify previous ichnological interpretations based on the reference material from Lesotho and

465 have enabled us to corroborate the identification of a putative trackmaker and its limb posture.

466 Moreover, the studied material sheds light on the trackmaker autopod posture. The smaller tracks

467 (e.g., MPCA27029-16) are here interpreted to have been left by a juvenile trackmaker and

468 allowed to appreciate that track morphology and structure are uniform in different ontogenetic

469 stages of the same type of producer.

$470 \quad$ Number of digit imprints, symmetry of manus and pes track, morphology of ungual

471 traces, limb posture and morphologically homopodic manus and pes tracks indicate the producer

472 of Pentasauropus to be sought among dicynodonts of the clade Kannemeyeriiformes (Fröbisch,

473 2009). Within this panorama and accepting the proposed palaeozoological attribution,

474 Pentasauropus tracks represent a valuable datum, further enriching the dicynodont record of the

475 Triassic of Argentina (Cox, 1962; Bonaparte, 1969, 1971, 1981; Lucas, 1998, 2010, 2018;

476 Rogers et al., 2001; Zavattieri \& Arcucci, 2007; Fröbisch, 2009; Domnanovich \& Marsicano,

477 2012; Abdala et al., 2013; Mancuso et al., 2014).

478 The studied tracks enabled us to improve the knowledge of the therapsid faunas from

479 south-western Gondwana, especially about their locomotion and functionality of fore and hind

480 autopods. The inferred limb posture of the Pentasauropus trackmaker finds a match with the

481 osteological data provided by the therapsid record (e.g., King, 1981a; Fröbisch, 2006) and allows

482 to corroborate interpretations derived from body-fossils. Meristic and qualitative track 
483 characteristics and trackway parameters, if jointly considered, suggest that the Pentasauropus

484 trackmaker had a semi-erect to erect posture, especially the hind limbs (Fig. 11A-B).

485 Contrarily to what was stated about therapsid posture in the past (Charig, 1980;

486 Bonaparte, 1982), therapsid-grade limb osteology was characterized by several important

487 modifications, which indicate a more parasagittal stance of the limbs (Romer, 1956; Boonstra,

488 1967; Jenkins, 1971), especially if compared with the prevalent sprawling posture of non-

489 therapsid synapsids (Romer, 1956; Hopson, 2015). Modifications of the scapula and the glenoid

490 have allowed the elbow to rotate inwardly, bringing the humerus closer to the sagittal plane

491 (Walter, 1986). The iliac blade was expanded anteriorly and allowed the insertion of a larger

492 iliofemoralis muscle (i.e., the muscle that allows movement of the femur with respect to the hip),

493 enabling femoral retraction (Romer, 1956; Walter, 1986). Moreover, the femoral head folded

494 medially and enabled a more parasagittal position of the propodial (Romer, 1922; Walter, 1986).

495 Concerning the dynamics of locomotion in non-mammalian therapsids, Kemp (1978)

496 proposed a dual-gait condition, intermediate between the plesiomorphic gait of amniotes

497 (Sumida \& Modesto, 2001) and the mammalian erect gait, based on the therocephalian

498 Regisaurus jacobi. This condition has proved to be not possible for derived dicynodonts, such as

499 Kingoria nowacki (sensu King, 1985) and for kannemeyeriiformes dicynodonts, all characterized

500 by an ankle joint inhibiting extensive rotational movements needed for dual-gait locomotion

501 (Fröbisch, 2006). In dicynodonts, the forelimb step cycle was performed in an abducted (i.e.

502 sprawling) posture, whereas the hind limb step cycle passed from a primitive abducted posture in

503 earlier members, such as Robertia broomiana (see King, 1981b) to an adducted (i.e. erect)

504 posture in more derived taxa (Walter, 1986), such as Dicynodon trigonocephalus and

505 Tetragonias njalilus (e.g., King, 1981a; Fröbisch, 2006). 

reconstructions derived from the body-fossil record. As stated before, the alleged autopodial structure inferred from Pentasauropus tracks is dictated by the relative distance between the proximal portion of digital (ungual) traces and the distal edge of the sub-circular pad trace, which has been inferred to relate to a fleshy pad behind the basipodial. The observed track morphology seems to imply that, except for acropodial and the fleshy pad, no other bony elements of the

512 producer's autopods were imprinted on the substrate, indicating that they were likely raised in

513 position. Such a configuration is considered valid for the foot bones in a static-state and would

514 fall at least within a subunguligrade posture, implying that the phalanges were the only bony

515 pedal elements contacting the ground in a static stance. However, if the three-dimensional

516 footprint morphology is considered (i.e. ungual traces and pad trace behind them) concurrently

517 with spatial data regarding pad trace/digit trace distance (Table 2), it is evident that the unguals

518 were not the only pedal elements performing the cycle of locomotion. Thus, the foot cannot be

519 regarded as subunguligrade from a dynamic point of view. During locomotion, the body weight

520 of Pentasauropus producers was not carried only by phalanges but, most likely, the entire foot

521 supported the load (Figs. 11, 12). The fleshy pad behind the basipodials actively contacted the

522 ground most likely during the touch-down and weight-bearing phase, as was already inferred

523 from footprint depth of impression in other producers (e.g., Romano, Citton \& Nicosia, 2016;

524 Citton et al., 2017). Thus, from a functional standpoint, the autopod posture of the

525 Pentasauropus trackmaker can be regarded as plantiportal (sensu Michilsens et al., 2009) and it

526 is considered to have been maintained during different gaits. Such a posture could have been

527 accompanied by an arched configuration of the articulated metapodials and at least of the

528 proximal phalanges (Kümmell \& Frey, 2012) (Fig. 11C-D). Metacarpals forming an arched 
529 configuration when articulated were described in a specimen of Tetragonias njalilus

530 (Cruickshank, 1967), and this kind of configuration could have been accompanied by little

531 movement capabilities (Rubidge \& Hopson, 1996) of the metapodials and could have dictated

532 the observed relative position of the ungual traces. A manual/pedal structure like the one here

533 hypothesized could have maintained a large surface in contact with the ground by means of

534 cartilaginous elements and fleshy cushions on which the basipodials rested, ensuring a

535 supportive role of the whole autopods during the cycle of locomotion and particularly during the

536 maximum load. Digit traces were formed by phalanges deeply penetrating into the substrate

537 during the final weight-bearing phase, kick-off and thrust. This could explain the different depth

538 of the impression that is observed in completely preserved tracks. Among digits the series II-IV,

539 and with a lesser extent digit I, played a major role in performing the end of the cycle of

540 locomotion. Drag traces affecting the most medial digits could be formed during the recovery of

541 the autopod at the end of the step.

542 A functionally plantiportal posture has been described in several mammals regardless of

543 body-weight (e.g., South-American coati, aardvark, armadillo, coypu, among others; see

544 Michilsens et al., 2009) but also can represent a functional strategy, co-occurring with a

545 graviportal structure of the limbs. A subunguligrade-plantiportal foot implies a complex set of

546 associated characters in the autopodial anatomy of the Pentasauropus producer. Body mass of

547 taxa similar to the alleged producer of Pentasauropus have been estimated to be $23-32 \mathrm{~kg}$ (based

548 on a juvenile individual of Dinodontosaurus; see Morato, 2006), $170 \mathrm{~kg}$ (based on an adult

549 specimen of Dinodontosaurus brevirostris; see Mancuso et al., 2014) up to $362 \mathrm{~kg}$ (based on an

550 adult individual of Dinodontosaurus platyceps; see Mancuso et al., 2014). The subunguligrade-

551 plantiportal autopod posture was most likely promoted in these dicynodonts and in the putative 
552 producer of Pentasauropus regardless of the body-dimension. Thus, this character not

553 necessarily implies an increase in body size but it is a pre-requisite for those lineages which

554 experienced an increase in body-dimension.

555 The Vera Formation and the track record: chronostratigraphical observations

556 As before stated, Pentasauropus or Pentasauropus-like footprints were reported to date mainly

557 from Upper Triassic units. In Argentina, Pentasauropus tracks were reported both from Upper

558 Triassic unit (e.g., Portezuelo Formation) and from late Middle Triassic unit (Cerro de Las

559 Cabras Formation). In Lesotho (Southern Africa), Pentasauropus was reported from the lower

560 Elliot Formation (Stormberg Group), which lies above the Carnian Molteno Formation. The

561 lower Elliot Formation was considered Upper Triassic by Ellenberger (1970), Norian-Rhaetian

562 by Olsen \& Galton (1984) and Norian by Knoll (2004), Lucas \& Hancox (2001) and Lucas

563 (2018), based on fossil remains, both bones and trace fossils. Recently, the Elliot Formation

564 (lower and upper) was discussed by means of magnetostratigraphy, and fixed as Upper Triassic -

565 Lower Jurassic by Sciscio et al. (2017). The same authors confirmed a Norian-Rhaetian age for

566 the lower Elliot Formation and correlated the unit with the Los Colorados Formation in the

567 Ischigualasto-Villa Union Basin of Argentina (Sciscio et al., 2017). A Late Triassic age of

568 Pentasauropus-bearing levels of the Vera Formation (most probably the upper portion of this

569 lithostratigraphic unit) is here accepted based on the currently shared distribution of the

570 ichnogenus.

571 At the same time, the recent datations provided by Luppo et al. (2017) contrast with the

572 Late Triassic age historically proposed for the whole Vera Formation and in particular for the

573 deposits bearing the 'Dicroidium' flora and the ichnogenus Dicynodontipus. On the basis of the

574 new isotopic ages, Luppo et al. (2017) concluded that at least some of the levels bearing the 
575 'Dicroidium'-type flora (Artabe, 1985a, b) are intercalated between deposits dated $252 \pm 2 \mathrm{Ma}$

576 (Changhsingian, Late Permian) and $248 \pm 2 \mathrm{Ma}$ (Olenekian, Early Triassic). These authors also

577 suggested that the stratigraphic position of the deposits exposed in the Tchering quarry, west of

578 Los Menucos town, where Dicynodontipus (sensu Melchor \& de Valais, 2006) come from, is not

579 yet completely clear. Nevertheless, this quarry is spatially close to the outcrops where

580 geochronological data were provided by Luppo et al. (2017). On the other hand, the Yancaqueo

581 farm from which the Pentasauropus footprints come, is located east of Los Menucos town and

582 lacks detailed geochronological and geological studies.

583 Thus, taking into account these new data and the chronostratigraphical distribution of

584 Dicynodontipus (e.g., Haubold, 1983; Ceoloni et al., 1988; Retallack, 1996; de Klerk, 2002;

585 Marsicano et al., 2004; Hunt \& Lucas, 2007; Klein \& Lucas, 2010; Costa da Silva, Sedor \&

586 Sequeira Fernandes, 2012; Fichter \& Kunz, 2013; Díaz-Martínez et al., 2015; Francischini et al.,

587 2018), the historically proposed Late Triassic age for the the strata of the Vera Formation bearing

588 Dicynodontipus (most likely the lower portion of the unit) is here questioned.

589

590 CONCLUSIONS

591 Large pentadactyl tracks from the Upper Triassic Vera Formation of the Los Menucos Group

592 (Río Negro province, North Patagonia, Argentina) were studied and discussed in terms of 593 palaeobiological attribution.

594 The tracks are currently referred to as Pentasauropus Ellenberger 1970, an ichnotaxon

595 established from the Upper Triassic lower Elliot Formation (Stormberg Group) of Karoo Basin 596 (Lesotho, Southern Africa). 
Material under study allowed to more effectively appreciate ichnotaxon variability and

598 proved to be significant for a better definition of the locomotor dynamics of the producer and 599 particularly of its foot anatomy.

$600 \quad$ Track and trackway parameters indicate a dicynodont as the most probable producer, and 601 a relationship with the South-American members of the clade Kannemeyeriiformes is proposed. 602 An affinity between the Gondwanan therapsid ichnofauna and that from South Africa is 603 evident, as well as functional features of the autopods of the producer are considered significantly similar and may be related to the same autopodial anatomy shared by the clade. subunguligrade in static posture and plantiportal during locomotion. A large pad of connective tissue behind the basipodials and partially metapodials can be proposed for the heavy-footed producers of Pentasauropus. The cushion allowed to decrease the stress transferred to the bones and spread it on a larger area during the touch-down and weight-bearing phase of the locomotion cycle.

Finally, a Late Triassic age for the Pentasauropus-bearing levels of the Vera Formation is

612 accepted, based on the age of other lithostratigraphic units bearing Pentasauropus in South

613 Africa and United States. At the same time, a detailed stratigraphic study of the lower, bearing-

614 Dicynodontipus, strata of the Vera Formation is needed to corroborate palaeontological and 615 geochronological data and to account the validity of the Vera Formation as lithostratigraphic 616 unit.

617

\section{ACKNOWLEDGEMENTS}


619 I. Cerda and C. Muñóz of the Museo Provincial Carlos Ameghino (Cipolletti, Río Negro

620 province, Argentina), D. Ramos and S. Mercado of the Museo Municipal de Los Menucos (Los

621 Menucos, Río Negro province, Argentina) and R. Rial of the Museo Provincial María Inés Kopp

622 (Valcheta, Río Negro province, Argentina) are kindly acknowledged for having made access to

623 Los Menucos material possible and for their assistance during museum operations. U. Nicosia is

624 warmly thanked for having reviewed an advanced draft of the manuscript. C. F. Kammerer is

625 sincerely thanked for having discussed some aspects of the autopod osteology in

626 kannemeyeriiformes. S. Lucas, H. Klein, P. Dentzien-Dias and the Academic Editor K. De Baets

627 are acknowledged for having provided revisions that significantly improved the manuscript. F.

628 Manucci is thanked for having performed the artworks.

629

630

\section{REFERENCES}

631 Abdala F, Marsicano CA, Smith RMH, Swart R. 2013. Strengthening Western Gondwanan

632 correlations: A Brazilian Dicynodont (Synapsida, Anomodontia) in the Middle Triassic of

633 Namibia. Gondwana Research 23 (3): 1151-1162. DOI: 10.1016/j.gr.2012.07.011

634 Anderson JM, Anderson HM, Cruickshank ARI. 1998. Late Triassic ecosystems of the

635 Molteno/Lower Elliot biome of Southern Africa. Palaeontology 41: 387-421.

636 Artabe AE. 1985a. Estudio sistemático de la tafoflora triásica de Los Menucos, provincia de Río 637 Negro, Argentina. Parte I. Ameghiniana 22(1-2): 3-22.

638 Artabe AE. 1985b. Estudio sistemático de la tafoflora triásica de Los Menucos, provincia de Río

639 Negro, Argentina. Parte II. Ameghiniana 22(3-4): 197-212. 
640 Avanzini M, Piñuela L, García-Ramos JC. 2011. Late Jurassic footprints reveal walking

641 kinematics of theropod dinosaurs. Lethaia 45(2): 238-252. DOI: 10.1111/j.1502-

$642 \quad 3931.2011 .00276 . x$

643 Baird D. 1980. A prosauropod dinosaur trackway from the Navajo Sandstone (Lower Jurassic) of 644 Arizona. In: Jacobs LL, ed. Aspect of Vertebrate History: essay in honor of Harris 645 Colbert. Flagstaff Museum of Northern Arizona Press, 219-230.

646 Barredo S, Chemale F, Ávila JN, Marsicano C, Ottone EG, Ramos VA, 2012. Tectono-sequence 647 stratigraphy and U-Pb zircon ages of the Rincón Blanco depocenter, northern Cuyo rift, 648 Argentina. Gondwana Research 21: 624-636. DOI: 10.1016/j.gr.2011.05.016

649 Belvedere M, Farlow JO. 2016. A Numerical Scale for Quantifying the Quality of Preservation 650 of Vertebrate Tracks. In: Falkingham PL, Marty D, Richter A, eds. Dinosaur tracks: the 651 next steps. Bloomington: Indiana University, Press, 93-98.

652 Bogan S, Taverne L, Agnolin F. 2013. First Triassic and oldest record of a South American 653 amiiform fish: Caturus sp. from the Los Menucos Group (lower Upper Triassic), Río 654 Negro province, Argentina. Geologica Belgica 16(3): 191-195.

Bonaparte JF. 1966. Cronología de algunas formaciones triásicas argentinas. Revista de la 656 Asociación Geológica Argentina 21: 20-38.

657 Bonaparte JF. 1969. Dos nuevas “faunas” de reptiles triásicos de Argentina. In: First Gondwana 658 Symposium, Mar del Plata 1967: Abstract book, 283-306.

659 Bonaparte JF. 1971. Annotated list of the South American Triassic tetrapods. Symposium on 660 Gondwana Stratigraphy. Proceedings and Papers, Pretoria 2: 665-682. 
661 Bonaparte JF. 1981. Nota sobre una nueva fauna del Triasico Inferior del Sur de Mendoza,

662 Argentina, correspondiente a la zona de Lystrosaurus (Dicynodontia-Proterosuchia). In:

663 Congreso Latino-Americano de Paleontologia, Abstract book, 277-288.

664 Bonaparte JF. 1982. Faunal replacement in the Triassic of South America. Journal of Vertebrate 665 Paleontology 2: 362-371. DOI: 10.1080/02724634.1982.10011938

666 Boonstra LD. 1967. An early stage in the evolution of the mammalian quadrupedal walking gait.

667 Annals of the South African Museum 50: 27-42.

668 Bordy EM, Abrahams M, Sciscio L. 2017. The Subeng vertebrate tracks: stratigraphy, 669 sedimentology and a digital archive of a historic Upper Triassic palaeosurface (lower Elliot Formation), Leribe, Lesotho (southern Africa). Bollettino della Società Paleontologica Italiana 56(2): 181-198. DOI: 10.4435/BSPI.2017.12

672 Carpenter K. 1992. Behavior of hadrosaurs as interpreted from footprints in the "Mesaverde" Group (Campanian) of Colorado, Utah, and Wyoming. Contributions to Geology, University of Wyoming 29(2): 81-96.

Casamiquela RM. 1964. Estudios icnológicos. Problemas y métodos de la icnología con aplicación al estudio de pisadas mesozoicas (Reptilia, Mammalia) de la Patagonia. Talleres Gráficos Colegio Industrial Pío IX, Buenos Aires.

678 Casamiquela RM. 1975. Nuevo material y reinterpretación de las icnitas mesozoicas (Neotriásicas) de Los Menucos, Provincia de Rio Negro (Patagonia). In: $1^{\circ}$ Congreso Argentino de Paleontologia y Biostratigrafia, Tucumán, Argentina 1974: Abstract book, 555-580.

682 Casamiquela RM. 1987. Novedades en icnología de vertebrados en la Argentina. In: $10^{\circ}$ Congreso Brasileiro de Paleontologia, Rio de Janeiro, Brazil: Abstract book 1, 445-456. 
684 Ceoloni P, Conti MA, Mariotti N, Nicosia U. 1988. New Late Permian tetrapod footprints from $685 \quad$ Southern Alps. Memorie della Società Geologica Italiana 34: 45-65.

686 Charig AJ. 1980. Differentiation of lineages among Mesozoic tetrapods. Mémoires de la Société 687 Géologique de France N.S. 59: 207-210.

688 Citton P, Carluccio R, Nicolosi I, Nicosia U. 2017. Re-evaluation of Chelichnus tazelwürmi, a 689 non mammalian therapsid-grade track from the Upper Permian Arenaria di Val Gardena. Historical Biology, DOI: 10.1080/08912963.2017.1370586

691 Costa da Silva R, Sedor FA, Sequeira Fernandes AC. 2012. Fossil footprints from the Late 692 Permian of Brazil: an example of hidden biodiversity. Journal of South American Earth 693 Sciences 38: 31-43. DOI: 10.1016/j.jsames.2012.05.001

Cox CB. 1962. Preliminary diagnosis of Ischigualastia, a new genus of dicynodont from Argentina. Breviora 156: 8-9.

Crompton AW, Jenkins Jr. FA. 1973. Mammals from Reptiles: a review of mammalian origins. Annual Review of Earth Planetary Science, 1: 131-155. DOI:

698 10.1146/annurev.ea.01.050173.001023

Cruickshank ARI. 1967. A new dicynodont genus from the Manda Formation of Tanzania (Tanganyika). Journal of Zoology 153: 163-208. DOI: 10.1111/j.1469-

701 7998.1967.tb04059.x

702 Cucchi R, Busteros A, Lema H. 2001. Hoja Geológica 4169 - II, Los Menucos, Provincia de Río 703 Negro. IGRM-SEGE-MAR Boletín 265: 1-105. Buenos Aires.

D’Orazi Porchetti S, Nicosia U. 2007. Re-examination of some large Early Mesozoic tetrapod 705 footprints from the African collection of Paul Ellenberger. Ichnos 14(3-4): 219-245. DOI: $10.1080 / 10420940601049990$ 
707 de Klerk WJ. 2002. A dicynodont trackway from the Cistecephalus Assemblage Zone in the

708 Karoo, east of Graaff-Reinet, South Africa. Palaeontologia Africana 38: 73-91.

$709 \quad$ http://hdl.handle.net/10539/16345

710 de Valais S. 2008. Icnología de tetrápodos triásicos y jurásicos de Argentina: aportes al origen de

711 las aves y los mamíferos. D. Phil Thesis, Universidad de Buenos Aires, Facultad de

712 Ciencias Exactas y Naturales.

713 de Valais S, Melchor RN, Bellosi E. 2006. New large vertebrate footprints from the Cerro de Las

714 Cabras Formation (Middle Triassic), Mendoza province. Ameghiniana 43 (suppl.): 34R.

715 Díaz-Martínez I, Castanera D, Gasca JM, Canudo JI. 2015. A reappraisal of the Middle Triassic

716 chirotheriid Chirotherium ibericus Navás, 1906 (Iberian Range NE Spain), with

717 comments on the Triassic tetrapod track biochronology of the Iberian Peninsula. PeerJ

$718 \quad 3: e 1044$. DOI $10.7717 /$ peerj. 1044

719 Díaz-Martínez I, de Valais S. 2014. Estudio de la variabilidad en la conservación de huellas de tetrápodos del Triásico Superior de Los Menucos, Río Negro, Argentina. Ameghiniana 52 (suppl. 1): 8 .

Domnanovich NS, Marsicano C. 2006. Tetrapod footprints from the Triassic of Patagonia:

(123.
reappraisal of the evidence. Ameghiniana 43(1): 55-70.

Domnanovich NS, Marsicano C. 2012. The Triassic dicynodont Vinceria (Therapsida,

Domnanovich NS, Tomassini R, Manera de Bianco T, Dalponte M. 2008. Nuevos aportes al 45: 173-186. DOI: 10.1016/j.geobios.2011.03.003 conocimiento de la icnofauna de tetrápodos del Triásico Superior de Los Menucos (Complejo Los Menucos), provincia de Río Negro, Argentina. Ameghiniana 45(1): 221224. 
731 Duncan H. 1831. An account of the tracks and footmarks of animals found impressed on

732

733

734

735

736

737

738

739

740

741

742

743

744

745

746

747

748

749

750

751

752

753

sandstone in the quarry of Corncockle Muir, in Dumfriesshire. Transactions of the Royal Society of Edinburgh 11: 194-209. DOI: 10.1017/S0080456800021906

Ellenberger P. 1955. Note préliminaire sur les pistes et les restes osseux de Vertébrés du Basutoland (Afrique du Sud). Comptes Rendus Hebdomadaires des Séances de l'Académie des Sciences 240: 889-891.

Ellenberger P. 1970. Les niveaux paléontologiques de premiére apparition des mammiféres primordiaux en Afrique du Sud et leur ichnologie. Establissement de zones stratigraphique détaillées dans le Stormberg du Lesotho (Afrique du Sud) (Trias superior a Jurassique). Proceedings and Papers II Gondwana Symposium 1970: 343-370.

Ellenberger P. 1972. Contribution à la classification des Pistes de Vertébrés du Trias: Les types du Stormberg d'Afrique du Sud (I). Paleovertebrata, Memoire Extraordinaire, Montpellier: $152 \mathrm{p}$.

Ellenberger F, Ellenberger P. 1958. Principaux types de pistes de vertébrés dans les couches du Stormberg au Basutoland (Afrique du Sud) (Note préliminaire). Comptes-Rendus sommaire des Séances de la Société géologique de France: 65-67.

Falk AR, Hasiotis ST, Gong E, Lim J-D, Brewer ED. 2017. A new experimental setup for studying avian neoichnology and the effects of grain size and moisture content on tracks: trials using the domestic chicken (Gallus gallus). Palaios 32 (11): 689-707.

Falkingham PL, Bates KT, Avanzini M, Bennett M, Bordy E, Breithaupt BH, Castanera D, Citton P, Díaz-Martínez I, Farlow JO, Fiorillo AR, Gatesy SM, Getty P, Hatala KG, Hornung JJ, Hyatt JA, Klein H, Lallensack JN, Martin AJ, Marty D, Matthews NA, Meyer ChA, Milàn J, Minter NJ, Razzolini NL, Romilio A, Salisbury SW, Sciscio L, Tanaka I, Wiseman ALA, 
754 Xing LD, Belvedere M. 2018. A standard protocol for documenting modern and fossil 755 ichnological data. Palaeontology (2018): 1-12. DOI: 10.1111/pala.12373

756 Fichter J, Kunz R. 2013. "Dinosauromorph” tracks from the Middle Buntsandstein (Early 757 Triassic: Olenekian) of Wolfhagen, northern Hesse, Germany. Comunicações Geológicas

Francischini H, Dentzien-Dias P, Lucas SG, Schultz CL. 2018. Tetrapod tracks in Permo100 (1): 81-88. http://www.Ineg.pt/iedt/unidades/16/paginas/26/30/141

765

766

767

768

769

770

771

772

773

774

775

776

Triassic eolian beds of southern Brazil (Paraná Basin). PeerJ 6: e4764. DOI: $10.7717 /$ peerj. 4764

Franzese JR, Spalletti LA. 2001. Late Triassic-Early Jurassic continental extension in southwestern Gondwana: tectonic segmentation and pre-break-up rifting. Journal of South American Earth Sciences 14: 257-270. DOI: 10.1016/S0895-9811(01)00029-3

Fröbisch J. 2006. Locomotion in derived dicynodonts (Synapsida, Anomodontia): a functional analysis of the pelvic girdle and hind limb of Tetragonias njalilus. Canadian Journal of Earth Sciences 43: 1297-1308. DOI: 10.1139/e06-031

Fröbisch J. 2009. Composition and similarity of global anomodont-bearing tetrapod faunas. Earth-Science Reviews 95: 119-157. DOI:10.1016/j.earscirev.2009.04.001

Gallego OF. 2010. A new crustacean clam shrimp (Spinicaudata: Eosestheriidae) from the Upper Triassic of Argentina and its importance for 'conchostracan' taxonomy. Alcheringa: An Australasian Journal of Palaeontology 34: 179-195. DOI: 10.1080/03115510903546152

Galton PM, Heerden van J. 1998. Anatomy of the prosauropod dinosaur Blikanasaurus cromptoni (Upper Triassic, South Africa), with notes on the other tetrapods from the Lower Elliot Formation. Paläontologische Zeitschrift 72: 163-177. DOI: 10.1007/BF02987824 
777 Gaston R, Lockley MG, Lucas SG, Hunt AP. 2003. Grallator- dominated fossil footprints

778 assemblages and associated enigmatic footprints from the Chinle Group (Upper Triassic),

779 Gateway Area, Colorado. Ichnos 10: 153-163. DOI: 10.1080/10420940390256258

780 González SN, Greco GA, Sato AM, Llambías EJ, Basei MAS, Gonzalez PD, Díaz PE. 2017.

781 Middle Triassic trachytic lava flows associated with coeval dyke swarm in the North

782 Patagonian Massif: a postorogenic magmatism related to extensional collapse of the

783 Gondwanide orogen. Journal of South American Earth Sciences 75: 134-143. DOI:

784

785

786

Haubold H. 1984. Saurierfährten. Die Neue Brehm-Bucherei, A. Ziemsen Verlagl, Wittenberg

Haubold H. 1974. Die fossilien Saurierfährten. A. Ziemsen, Wittenberg.

Haubold H. 1983. Archosaur evidence in the Buntsandstein (Lower Triassic). Acta Palaeontologica Polonica 28 (1-2): 123-132. Lutherstadt.

Hitchcock E. 1836. Ornithichnology - description of the foot marks of birds (Ornithichnites) on New Red Sandstone in Massachusetts. American Journal of Science 29: 307-340.

792

793

794

795

796

797

798 10.1016/j.jsames.2017.02.007

Hopson JA. 1995. Patterns of evolution in the manus and pes of nonmammalian therapsids. Journal of Vertebrate Paleontology 15: 615-639. DOI:

$10.1080 / 02724634.1995 .10011252$

Hopson JA. 2015. Fossils, trackways, and transitions in locomotion: a case study of Dimetrodon. In: Dial KP, Shubin N, Brainerd EL, eds. Great transformations in vertebrate evolution. Chicago: The University of Chicago Press, 125-141. DOI: 10.7208/chicago/9780226268392.001.0001 
799 Huene F. von. 1931. Die fossilen Fährten im Rhät von Ischigualasto in Nordwest-Argentinien.

$800 \quad$ Palaeobiologica 4: 99-112.

801 Hunt AP, Lucas SG. 2007. The Triassic tetrapod track record: ichnofaunas, ichnofacies and 802 biochronology. New Mexico Museum of Natural History and Science Bulletin 41:78-87.

803 Hunt AP, Lucas SG, Klein H. 2018. Late Triassic nonmarine vertebrate and invertebrate trace 804 fossils and the pattern of the Phanerozoic record of vertebrate trace fossils. In: Tanner 805 LH, ed. The Late Triassic World. Cham: Springer International Publishing, 447-544. DOI: $10.1007 / 978-3-319-68009-5+12$

807 Hunt-Foster RK, Lockley MG, Milner ARC, Foster JR, Matthews NA, Breithaupt BH, Smith JA. 808 2016. Tracking dinosaurs in BLM canyon country, Utah. Geology of the Intermountain $809 \quad$ West 3: 67-100.

810 Jenkins FA, Jr. 1971. The postcranial skeleton of African cynodonts. Peabody Museum of 811 Natural History, Yale University, Bulletin 36: 1-216.

812 Kammerer CF. 2018. The first skeletal evidence of a dicynodont from the lower Elliot Formation of South Africa. Palaeontologia africana 52: 102-128.

814 http://wiredspace.wits.ac.za/handle/10539/24148

815 Kaup JJ. 1835a. Über Thierfährten bei Hildburghausen. Neues Jahrbuch für Mineralogie, $816 \quad$ Geologie und Paläontologie 1835: 327-328.

817 Kaup JJ. 1835b. Fährten von Beuteltieren. In Das Tierreich: 246-248.

818 Kemp TS. 1978. Stance and gait in the hindlimb of a therocephalian mammal-like reptile.

819 Journal of Zoology 186: 143-161. DOI: 10.1111/j.1469-7998.1978.tb03362.x

820 King GM. 1981a. The functional anatomy of a Permian dicynodont. Philosophical Transaction 821 of the Royal Society of London B 291: 243-322. DOI: 10.1098/rstb.1981.0001 
822 King GM. 1981b. The post cranial skeleton of Robertia broomiana, an early dicynodont

823 (Reptilia, Therapsida) from the South African Karoo. Annals of South African Museum

$824 \quad 84: 203-231$.

825 King GM. 1985. The postcranial skeleton of Kingoria nowacki (von Huene) (Therapsida:

826 Dicynodontia). Zoological Journal of the Linnean Society 84: 263-298. DOI:

$827 \quad 10.1111 / \mathrm{j} .1096-3642.1985 . t b 01801 . x$

828 Klein H, Lucas SG. 2010. Tetrapod footprints - their use in biostratigraphy and biochronology of

829 the Triassic. In: Lucas SG, ed. The Triassic Timescale. Geological Society, London,

$830 \quad$ Special Publications 334: 419-446. DOI: 10.1144/SP334.14

831 Knoll F. 2004. Review of the tetrapod fauna of the "Lower Stormberg Group" of the main Karoo

832 Basin (southern Africa): implication for the age of the Lower Elliot Formation. Bulletin

833 de la Societe géologique de France 175(1): 73-83. DOI: 10.2113/175.1.73

834 Kokogian DA, Spalletti L, Morel E, Artabe A, Martínez RN, Alcober OA, Milana JP, Zavattieri

835 AM, Papù OH. 1999. Los depósitos continentales triásicos. In: Caminos R, Panza J, eds.

836 Geología Argentina, Instituto de Geología y Recursos Minerales. Buenos Aires, Anales, $837 \quad 29(15), 377-398$.

838 Kubo T, Benton MJ. 2009. Tetrapod postural shift estimated from Permian and Triassic 839 trackways. Palaeontology 52: 1029-1037. DOI: 10.1111/j.1475-4983.2009.00897.x

840 Kubo T, Ozaki M. 2009. Does pace angulation correlate with limb posture? Palaeogeography,

841 Palaeoclimatology, Paleoecology 275: 54-58. DOI: 10.1016/j.palaeo.2009.02.001

842 Kümmell S, Frey E. 2012. Digital arcade in the autopodia of Synapsida: standard position of the

843 digits and dorsoventral excursion angle of digital joints in the rays II-IV. 

0076-6

846 Labudía CH, Bjerg EA. 2001. El Grupo Los Menucos: redefinición estratigráfica del Triásico Superior del Macizo Nordpatagonico. Revista de la Asociación Geologica Argentina 56: 404-407.

Labudía CH, Bjerg EA. 2005. Geología del Grupo Los Menucos, Comarca Nordpatagónica, Argentina. In: $16^{\circ}$ Congreso Geológico Argentino, La Plata, Argentina: Abstract book, $233-238$.

Labudía CH, Llambías EJ, Rapela CW, Artabe AE. 1995. El Triásico de Los Menucos: procesos volcánicos y sedimentarios. In: $2^{\circ}$ Reunión del Triásico de Cono Sur, Bahía Blanca, Argentina: Abstract book, 17-21.

Lema H, Busteros A, Giacosa RE, Cucchi R. 2008. Geología del complejo volcánico Los

Leonardi G. 1987. Glossary and manual of tetrapod footprint palaeoichnology. Brasilia: Departamento Nacional da Produção Mineral.

Leonardi G. 1994. Annotated atlas of South America tetrapod footprints (Devonian-Holocene). Ministerio de Minas y Energia, Companhia de Pesquisa de Recursos Minerais, Brazil.

862 Leonardi G, de Oliveira FH. 1990. A revision of the Triassic and Jurassic tetrapod footprints of Argentina and a new approach on the age and meaning of the Botucatu Formation footprints (Brazil). Revista Brasileira de Geociencias 20: 216-229. Press, Cambridge. 
867 Lockley MG, Hunt AP. 1995. Dinosaur tracks and other fossil footprint of the Western United $868 \quad$ States. Columbia University Press, New York.

869 Lockley MG, McCrea RT, Buckley LG, Lim JD, Matthews NA, Breithaupt BH, Houck KJ, 870 Gierlinski GD, Surmik D, Kim KS, Xing L, Kong DY, Cart K, Martin J, Hadden G.

871 2016. Theropod courtship: large scale physical evidence of display arenas and avian-like 872 scrape ceremony behaviour by Cretaceous dinosaurs. Scientific Reports 6:18952. DOI:

873 $10.1038 /$ srep 18952

874 Lockley MG, Meyer CA. 2000. Dinosaur Tracks and other fossil footprints of Europe. Columbia $875 \quad$ University Press, New York.

876 Lucas SG. 1998. Global Triassic tetrapod biostratigraphy and biochronology. Palaeogeography, Palaeoclimatology, Palaeoecology 143: 347-384. DOI: 10.1016/S0031-0182(98)00117-5

Lucas SG. 2002. A new dicynodont from the Triassic of Brazil and the tetrapod biochronology of the Brazilian Triassic. New Mexico Museum of Natural History and Science Bulletin 880 21: $131-141$.

Lucas SG. 2010. The Triassic timescale based on nonmarine tetrapod biostratigraphy and 882 biochronology. In: Lucas SG, ed. The Triassic timescale. Geological Society, London, 883 Special Publications 334: 447-500. DOI: 10.1144/SP334.15

Lucas SG. 2018. Late Triassic Terrestrial Tetrapods: biostratigraphy, biochronology and biotic events In: Tanner LH, ed. The Late Triassic World. Cham: Springer International Publishing, 351-406. DOI: 10.1007/978-3-319-68009-5_12

887 Lucas SG, Hancox J. 2001. Tetrapod-based correlation of the nonmarine Upper Triassic of 888 Southern Africa. Albertiana 25: 5-9. 
889 Luppo T, López De Luchi MG, Rapalini AE, Martínez Dopico CI, Fanning CM. 2017.

890 Geochronologic evidence of a large magmatic province in northern Patagonia

891 encompassing the Permian-Triassic boundary. Journal of South American Earth Sciences

892 (2017): 1-10. DOI: 10.1016/j.jsames.2018.01.003

893 Mackenzie WS, Donaldson CH, Guilford C. 1982. Atlas of Igneous Rocks and Their Textures.

$894 \quad$ John Wiley, New York.

895 Mallison H, Wings O. 2014. Photogrammetry in Paleontology - a practical guide. Journal of

$896 \quad$ Paleontological Techniques 12: 1-31.

897 Mancuso AC, Gaetano LC, Leardi JM, Abdala F, Arcucci AB. 2014. The Chañares Formation: a

898 window to a Middle Triassic tetrapod community. Lethaia 47: 244-265. DOI:

$899 \quad 10.1111 /$ let. 12055

900 Marsicano CA, Arcucci AB, Mancuso A, Caselli AT 2004. Middle Triassic tetrapod footprints of $901 \quad$ southern South America. Ameghiniana 41 (2): 171-184.

902 Marsicano CA, Barredo SP. 2004. A Triassic tetrapod footprint assemblage from southern South

903 America: palaeobiogeographical and evolutionary implications. Palaeogeography,

904 Palaeoclimatology, Palaeocology 203: 313-335. DOI: 10.1016/S0031-0182(03)00689-8

905 Marty D, Falkingham PL, Richter A. 2016. Dinosaur Track Terminology: A Glossary of Terms.

906 In: Falkingham PL, Marty D, Richter A, eds. Dinosaur tracks: the next steps.

907 Bloomington: Indiana University, Press, 399-402.

908 Melchor RN, de Valais S. 2006. A review of Triassic tetrapod track assemblages from Argentina.

909 Palaeontology 49(2): 355-379. DOI: 10.1111/j.1475-4983.2006.00538.x 
910 Melchor RN, Genise JF, Poiré DGG. 2001. Icnología de los depósitos continentales triásicos. In:

911 Artabe AE, Morel EM, Zamuner AB, eds. El Sistema Triásico en Argentina. Fundación

912 Museo de La Plata 'Francisco Pascasio Moreno', La Plata, 101-135.

913 Michilsens F, Aerts P, Van Damme R, D’Aout K. 2009. Scaling of plantar pressures in 914 mammals. Journal of Zoology 279: 236-242. DOI: 10.1111/j.1469-7998.2009.00611.x

915 Morato L. 2006. Dinodontosaurus (Synapsida, Dicynodontia): reconstituições morfológicas e 916 aspectos biomecânicos. Master Thesis, Universidade Federal do Rio Grande do Sul do 917 Porto Alegre, Instituto de Geociências, Área de Concentração Paleontologia.

918 Olsen PE, Galton PM. 1984. A review of the reptile and amphibian assemblages from the 919 Stormberg of southern Africa, with special emphasis on the footprints and the age of the 920 Stormberg. Paleontologica Africana 25: 87-110. http://hdl.handle.net/10539/16131

921 Peabody FE. 1948. Reptile and Amphibian trackways from the Lower Triassic Moenkopi 922 Formation of Arizona and Utah. Bulletin of the Department of Geological Sciences, $923 \quad$ Berkeley and Los Angeles 27: 295-468.

924 Peabody FE. 1959. Trackways of living and fossil salamanders. University of California $925 \quad$ Publications in Zoology 63: 1-72.

926 Rapela CW, Pankhurst RJ, Llambías EJ, Labudia CH, Artabe AE. 1996. Gondwana magmatism 927 of Patagonia: inner cordilleran calc-alkaline batholiths and bimodal volcanic provinces. In: $3^{\circ}$ International Symposium on Andean Geodynamics, Saint Malo, Extended Abstract

930 Retallack GJ. 1996. Early Triassic therapsid footprints from the Sidney Basin, Australia. Alcheringa 20: 301-314. DOI: 10.1080/03115519608619473 
932 Romano M, Citton P, Nicosia U. 2016. Corroborating trackmaker identification through footprint 933 functional analysis: the case study of Ichniotherium and Dimetropus. Lethaia 49: 102-

934 116. DOI: $10.1111 /$ let. 12136

935 Rogers RR, Arcucci A, Abdala F, Sereno PC, Forster CA, May CL. 2001. Paleoenvironment and 936 taphonomy of the Chanares Formation tetrapod assemblage (Middle Triassic),

937 northwestern Argentina: spectacular preservation in volcanogenic concretions. Palaios 16 938 (5): 461-481. DOI: 10.1669/0883-1351(2001)016<0461:PATOTC $>2.0 . C O ; 2$

939 Romer AS. 1922. The locomotor apparatus of certain primitive and mammal-like reptiles.

$940 \quad$ Bulletin of the American Museum of Natural History 46: 517-606.

$941 \quad$ http://hdl.handle.net/2246/929

942 Romer AS. 1956. Osteology of the Reptiles. Malabar (FL): Krieger Publishing Company.

943 Romer AS. 1966. The Chañares (Argentina) Triassic reptile fauna; I. Introduction. Breviora 247: $944 \quad 1-14$.

945 Rubidge BS, Hopson JA. 1996. A primitive anomodont therapsid from the base of the Beaufort 946 Group (Upper Permian) of South Africa. Zoological Journal of the Linnean Society 117:

947 115-139. DOI: 10.1111/j.1096-3642.1996.tb02152.x

948 Scasso RA, Limarino CO. 1997. Petrología y diagénesis de rocas clásticas. Asociación Argentina 949 de Sedimentología, Publicación Especial 1, 259 pp., Buenos Aires.

950 Sciscio L, de Kock M, Bordy E, Knoll F. 2017. Magnetostratigraphy over the Triassic-Jurassic 951 boundary in the main Karoo Basin. Gondwana Research 51: 177-192. DOI:

$952 \quad$ 10.1016/j.gr.2017.07.009 
953 Smith RMH. 1993. Sedimentology and ichnology of floodplain paleosurfaces in the Beaufort

954 Group (Late Permian), Karoo Sequence, South Africa. Palaios 8:339-357. DOI:

955 $10.2307 / 3515265$

956

Spalletti LA. 1999. Cuencas triásicas del Oeste argentino: origen y evolución. Acta Geológica 957 Hispánica 32: 29-50.

958

959

960

961

962

963

964

965

966

967

968

969

970

971

972 Zavattieri AM, Arcucci AB. 2007. Edad y posición estratigráfica de los tetrápodos del cerro

973

974

975

Stipanicic PN. 1967. Consideraciones sobre las edades de algunas fases magmáticas del Neopaleozoico y Mesozoico. Revista de la Asociación Geológica Argentina 22: 101-133.

Stipanicic PN, Methol EJ. 1972. Macizo de Somún Curá. In: Leanza AF, ed. Geología Regional Argentina. Academia Nacional de Ciencias de Córdoba: 581-600. Córdoba.

Stipanicic PN, Methol EJ. 1980. Comarca Norpatagónica. In: Geología Regional Argentina. Academia Nacional de Ciencias de Córdoba: 1071-1097. Córdoba.

Stipanicic PN, Rodrigo F, Baulies OL, Martínez CG. 1968. Las formaciones pre-senonianas en el denominado Macizo Nordpatagónico y regiones adyacentes. Revista de la Asociación Geológica Argentina 23: 67-98.

Sumida SS, Modesto SP. 2001. A phylogenetic perspective on locomotory strategies in early amniotes. American Zoologist 41: 586-597. DOI: 10.1093/icb/41.3.586

Walter LR. 1986. The limb posture of kannemeyeriid dicynodonts: functional and ecological consideration. In: Padian K, ed. The Beginning of the Age of Dinosaurs. Cambridge University Press, Cambridge: 89-97. Bayo de Potrerillos (Triásico), Mendoza, Argentina. Ameghiniana 44(1): 133-142. http://www.scielo.org.ar/scielo.php script=sci_arttext\&pid=S0002$70142007000100009 \& \operatorname{lng}=\mathrm{es} \& \mathrm{nrm}=\mathrm{iso}$ 
976

\section{Figure captions}

978 Figure 1 The Los Menucos area. (A) Location map and geological sketch of Los Menucos area 979 (from Labudía \& Bjerg, 2005, redrawn and slightly modified). White star indicates Estancia

$980 \quad$ Yancaqueo, from which the Pentasauropus footprints come. (B) Simplified stratigraphic

981 section of the Los Menucos Group (from Labudía \& Bjerg, 2005, redrawn and slightly

982 modified). Dashed lines with quotation marks indicate the possible position of

983 Pentasauropus-bearing strata.

984 Figure 2 Thin sections (MPCA 27029/19.1 and MPCA 27029/19.2) of track-bearing slab MPCA

985 27029-19. Inequigranular, epiclastic texture with anhedral and subhedral phenocrysts at the

986 base (A) and middle portion (B) of the track-bearing slab MPCA 27029-19. (C, D)

987 Equigranular less epiclastic texture indicating a minor sedimentary reworking of the trampled 988 surface.

989 Figure 3 Tracks mode of preservation. Convex hyporeliefs (A, C) fitting with concave epireliefs

990 (B, D) preserved on slab MMLM 075-1 (true tracks and natural casts, respectively).

991 Figure 4 Photos, three-dimensional models and interpretative drawings of the studied material.

992 (A) Track-bearing slabs MPCA 27029-1; (B) Solid three-dimensional model of (A); (C)

993 Colour topographic profile and (D) interpretative drawing of (A). (E) Track-bearing slabs

994 MPCA 27029-2; (F) Solid three-dimensional model of (E); (G) Colour topographic profile 995 and $(\mathrm{H})$ interpretative drawing of (E). In (A)-(D), footprint 2 and 5, note the non-impressed 996 area between the sole pad trace and the base of digit traces. In (E)-(H) note the displacement 997 areas behind digit traces, interpreted as the result of the thrust of digit pushing the sediment 998 backwardly. 
999 Figure 5 Photos, three-dimensional models and interpretative drawings of the studied material.

$1000 \quad$ (A) Track-bearing slabs MPCA 27029-3; (B) Solid three-dimensional model of (A); (C)

1001 Colour topographic profile and (D) interpretative drawing of (A). (E) Track-bearing slabs

1002 MPCA 27029-4; (F) Solid three-dimensional model of (E); (G) Colour topographic profile

1003 and $(\mathrm{H})$ interpretative drawing of $(\mathrm{E})$. Note the digit trailing marks slightly affecting the digit

1004 traces of footprint 2 in (A)-(D), which are absent in footprints showed in (E)-(H) where digit

1005 traces are roughly sub circular in morphology.

1006 Figure 6 Photos, three-dimensional models and interpretative drawings of the studied material.

1007 (A) Track-bearing slabs MPCA 27029-5; (B) Solid three-dimensional model of (A); (C)

1008 Colour topographic profile and (D) interpretative drawing of (A). (E) Track-bearing slabs

1009 MPCA 27029-9; (F) Solid three-dimensional model of (E); (G) Colour topographic profile

1010 and $(\mathrm{H})$ interpretative drawing of $(\mathrm{E})$.

1011 Figure 7 Photos, three-dimensional models and interpretative drawings of the studied material.

1012 (A) Track-bearing slabs MPCA 27029-16, produced by a juvenile trackmaker; (B) Solid

1013 three-dimensional model of (A); (C) Colour topographic profile and (D) interpretative

1014 drawing of (A). (E) Track-bearing slabs MPCA 27029-21; (F) Solid three-dimensional model

1015 of $(\mathrm{E}) ;(\mathrm{G})$ Colour topographic profile and $(\mathrm{H})$ interpretative drawing of $(\mathrm{E})$. The general

1016 morphology and structure of footprints 6-10 in (A)-(D), left by a juvenile trackmaker, is

1017 identical to that characterizing larger footprints, even when preserved only as digit traces.

1018 Figure 8 Photos, three-dimensional models and interpretative drawings of the studied material.

1019 (A) Track-bearing slabs MPCA 27029-33; (B) Solid three-dimensional model of (A); (C)

1020 Colour topographic profile and (D) interpretative drawing of (A). (E) Track-bearing slabs 
1021 MMLM 075-1; (F) Solid three-dimensional model of (E); (G) Colour topographic profile and

$1022(\mathrm{H})$ interpretative drawing of $(\mathrm{E})$. In $(\mathrm{E})-(\mathrm{H})$ note the long and sharp digit trailing marks.

1023 Figure 9 Photos, three-dimensional models and interpretative drawings of the studied material.

1024 (A) Track-bearing slabs MMLM 1; (B) Solid three-dimensional model of (A); (C) Colour

1025 topographic profile and (D) interpretative drawing of (A). (E) Track-bearing slabs MMLM 2;

1026 (F) Solid three-dimensional model of (E); (G) Colour topographic profile and (H)

1027 interpretative drawing of (E). In (A)-(D) note the long and sharp digit trailing marks affecting

1028 footprints 2 and 4, resembling those of Figure 8E-H.

1029 Figure 10 Morphological and extramorphological features identified on the studied material. (A)

1030 Manus track MPCA 27029/2 and (B) interpretative drawing. (C) Pes track MPCA 27029-1/5

1031 and (D) interpretative drawing. Extramorphological features are in blue and grey,

1032 morphological features are in black.

1033 Figure 11 Limb and autopod posture in the Pentasauropus trackmaker. Simplified reconstruction

1034 of limb posture in back (A) and lateral (B) views. Simplified reconstruction of zeugopodials

1035 and hind autopod in lateral (C) and bottom (D) views. In colour the possible extension of the

1036 fleshy cushion on which the basipodials rested, ensuring support during locomotion. See the

1037 supplementary video to get a more complete view of the reconstruction. Artwork by Fabio

1038 Manucci.

1039 Figure 12 Speculative in vivo reconstruction (based on Dinodontosaurus) of a

1040 kannemeyeriiformes dicynodont, a most probable producer of Pentasauropus tracks.

1041 Reconstruction in back (A) and lateral (B) view of the trackmaker walking in amble gait. See

1042 the supplementary video to get a more complete view of the reconstruction. Artwork by Fabio

1043 Manucci. 


\section{Table captions}

1045 Table 1 Photogrammetric report. Main processing parameters of the photogrammetric models

1046 (from Agisoft Photoscan Professional reports).

1047 Table 2 Mean measurements (in $\mathrm{cm}$ ) of track and trackway parameters. ETW, external trackway

1048 width; Fl, footprint length; Fw, footprint width; GAD, gleno-acetabular distance: (a),

1049 'primitive' alternate pace (the trunk length of the producer is underestimated); (b), alternate

1050 pace; (c), amble (a, b, c, considering primary overlap sensu Leonardi, 1987); ITW, internal

1051 trackway width; Mpa, manus pace angulation; Mpl, manus pace length; Msl, manus stride

1052 length; Ppa, pes pace angulation; Ppl, pes pace length; Psl, pes stride length; Psl/GAD, pes

1053 stride length/gleno-acetabular distance ratio; ETW/SL, external trackway width/stride length

1054 ratio.

1055 Table 3 Sole pad-ungual trace distance. Distance (in $\mathrm{cm}$ ) between the distal margin of the sole

1056 pad trace and the proximal margin of the digit traces in complete Pentasauropus footprints.

1057 The measurements most likely indicate a raised and inclined position of the metapodial

1058 elements of fore and hind foot in the Pentasauropus trackmaker. 


\section{Figure 1}

The Los Menucos area.

(A) Location map and geological sketch of Los Menucos area (from Labudía \& Bjerg, 2005, redrawn and slightly modified). White star indicates Estancia Yancaqueo, from which the Pentasauropus footprints come. (B) Simplified stratigraphic section of the Los Menucos Group (from Labudía \& Bjerg, 2005, redrawn and slightly modified). Dashed lines with quotation marks indicate the possible position of Pentasauropus-bearing strata. 


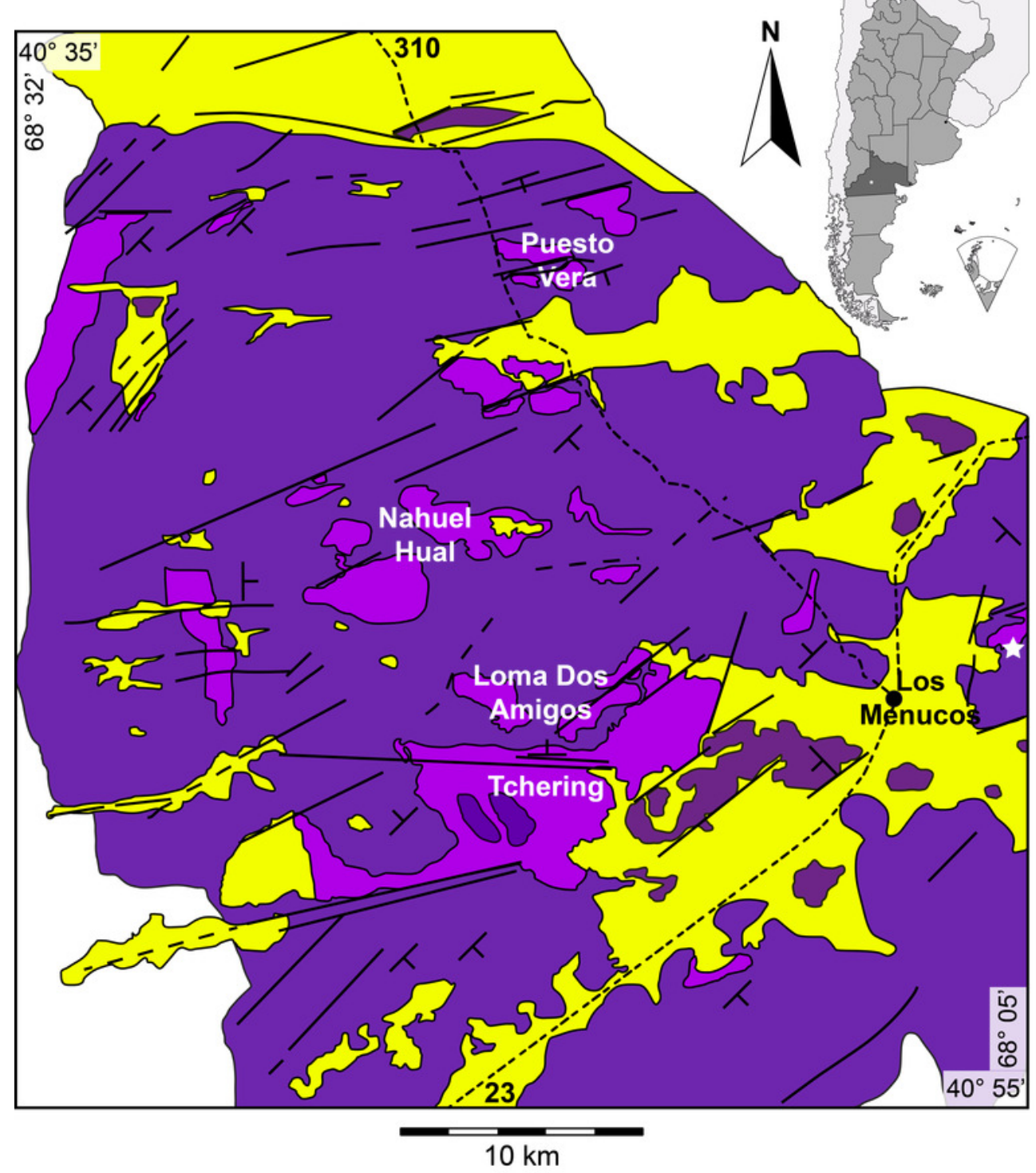

Scree and alluvial deposits
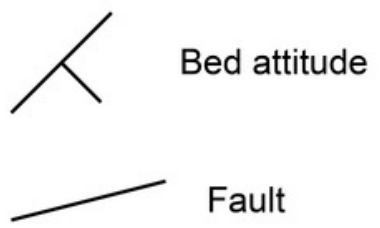

Sierra Colorada Fm.

$\ldots \ldots$ Inferred fault

Vera Fm.

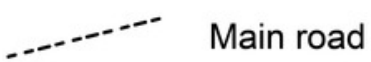

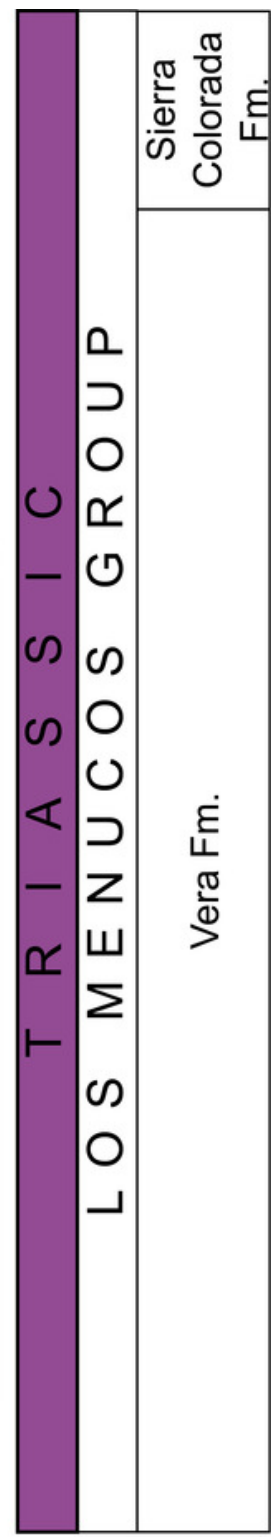
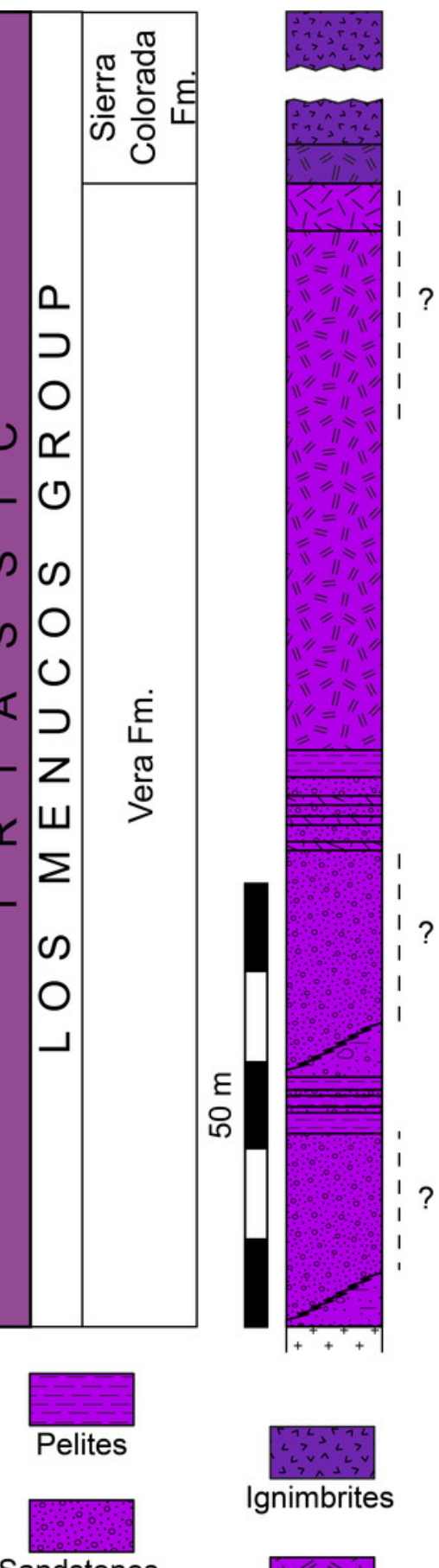

Sandstones

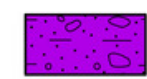

Conglomerates

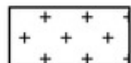

B Basement 
Figure 2

Thin sections (MPCA 27029/19.1 and MPCA 27029/19.2) of track-bearing slab MPCA 27029-19.

Inequigranular, epiclastic texture with anhedral and subhedral phenocrysts at the base $(A)$ and middle portion (B) of the track-bearing slab MPCA 27029-19. (C, D) Equigranular less epiclastic texture indicating a minor sedimentary reworking of the trampled surface.
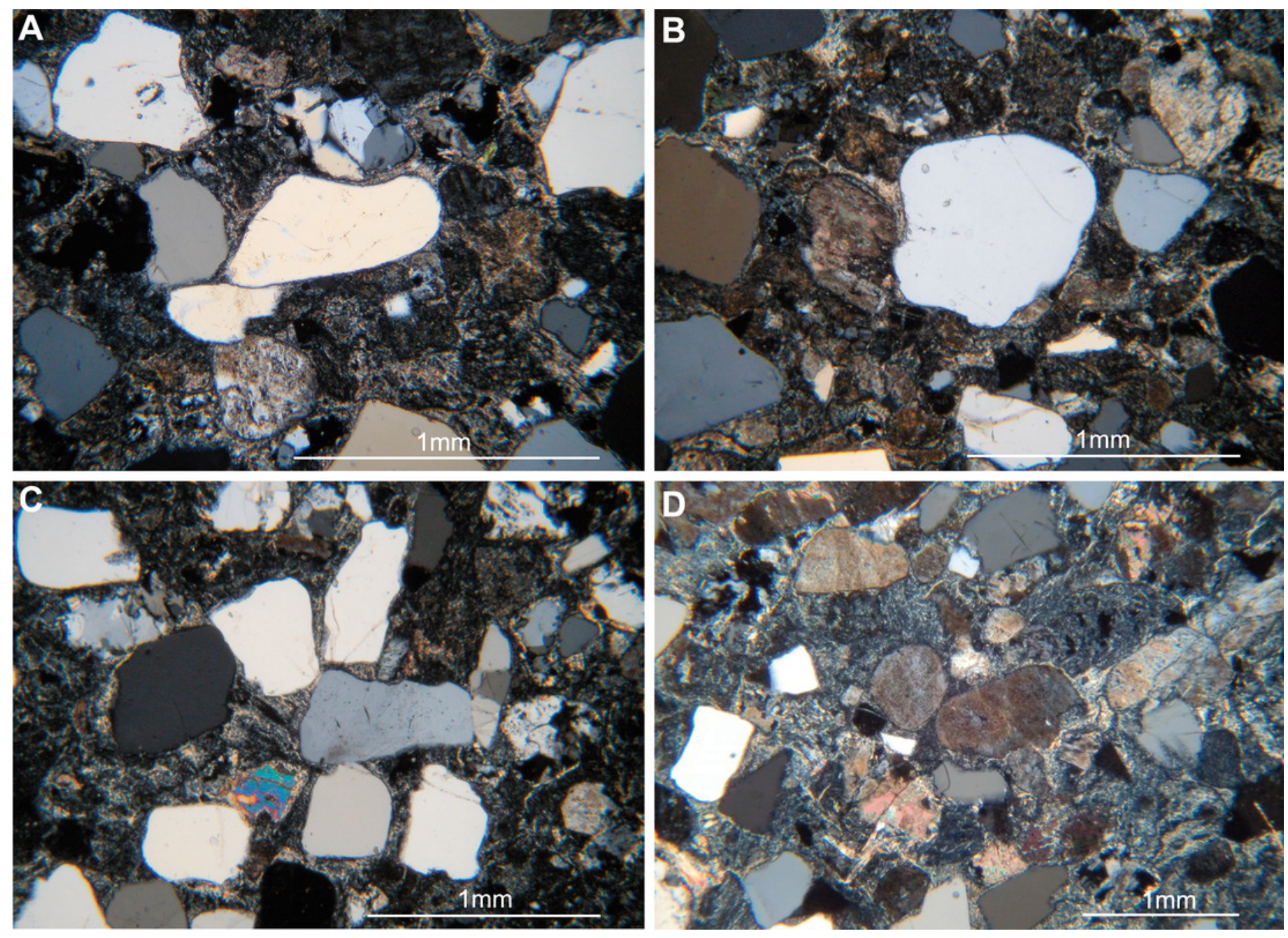
Figure 3

Tracks mode of preservation.

Convex hyporeliefs ( $\mathrm{A}, \mathrm{C})$ fitting with concave epireliefs $(\mathrm{B}, \mathrm{D})$ preserved on slab MMLM 075-1 (true tracks and natural casts, respectively).
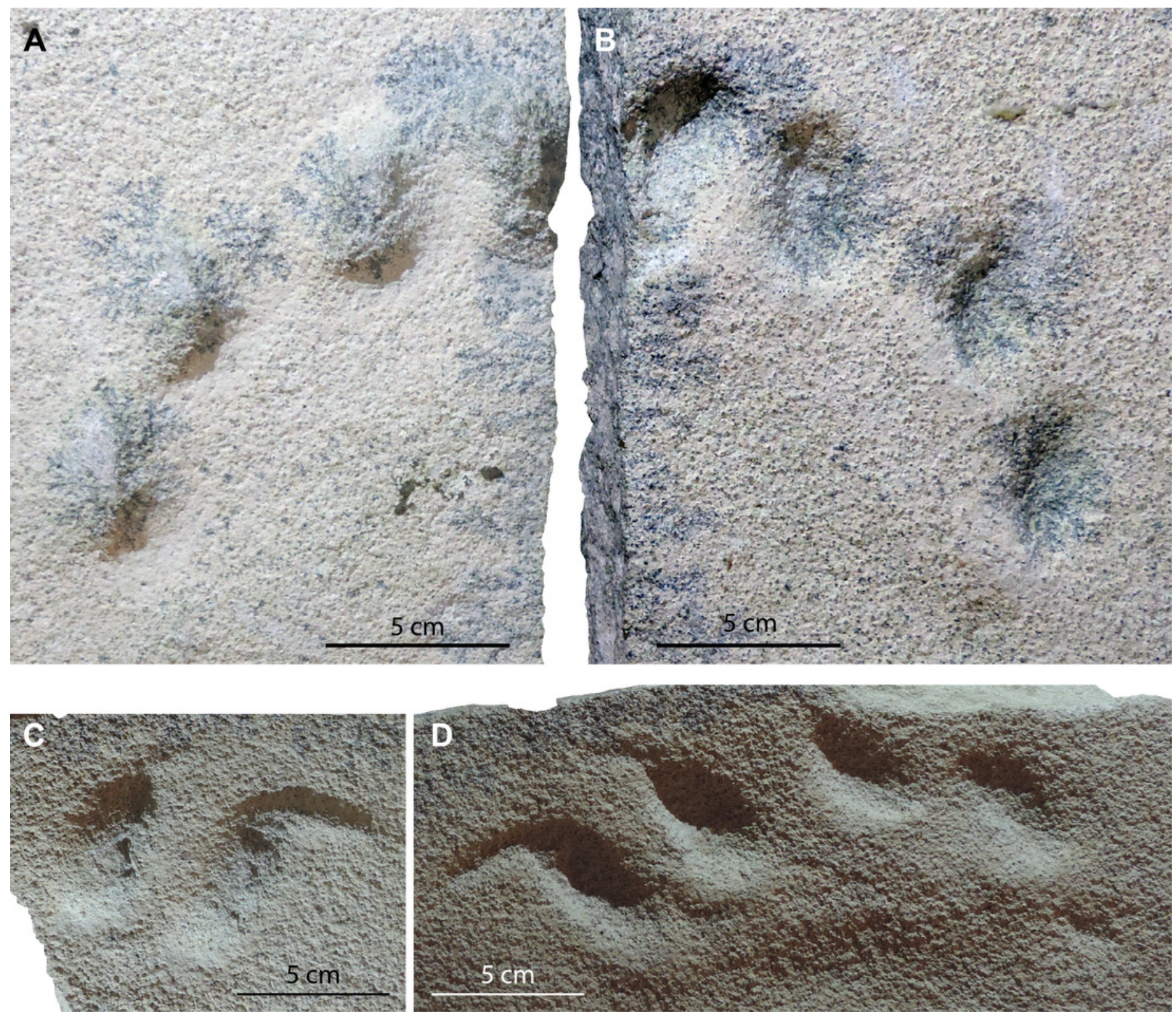


\section{Figure 4}

Photos, three-dimensional models and interpretative drawings of the studied material.

(A) Track-bearing slabs MPCA 27029-1; (B) Solid three-dimensional model of (A); (C) Colour topographic profile and (D) interpretative drawing of (A). (E) Track-bearing slabs MPCA 27029-2; (F) Solid three-dimensional model of (E); (G) Colour topographic profile and (H) interpretative drawing of (E). In (A)-(D), footprint 2 and 5 , note the non-impressed area between the sole pad trace and the base of digit traces. In (E)-(H) note the displacement areas behind digit traces, interpreted as the result of the thrust of digit pushing the sediment backwardly. 
A

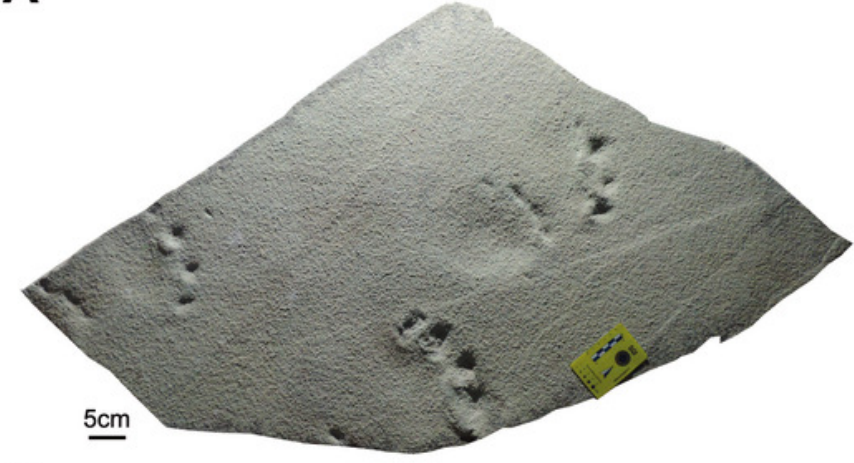

C

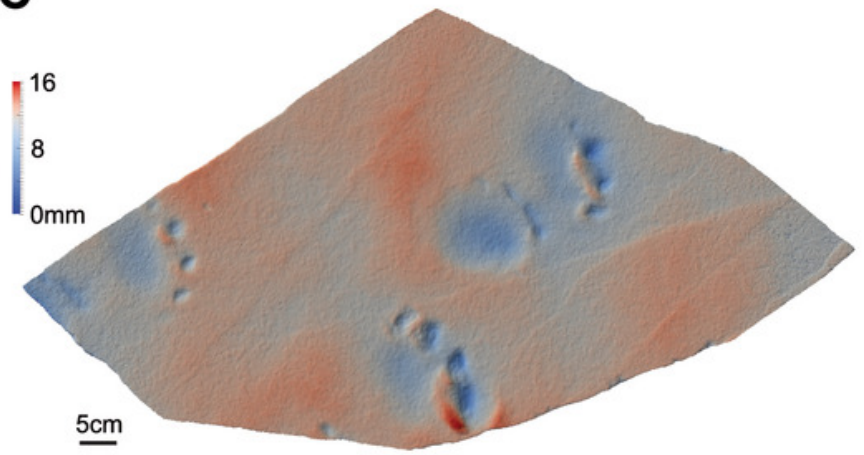

$\mathbf{E}$

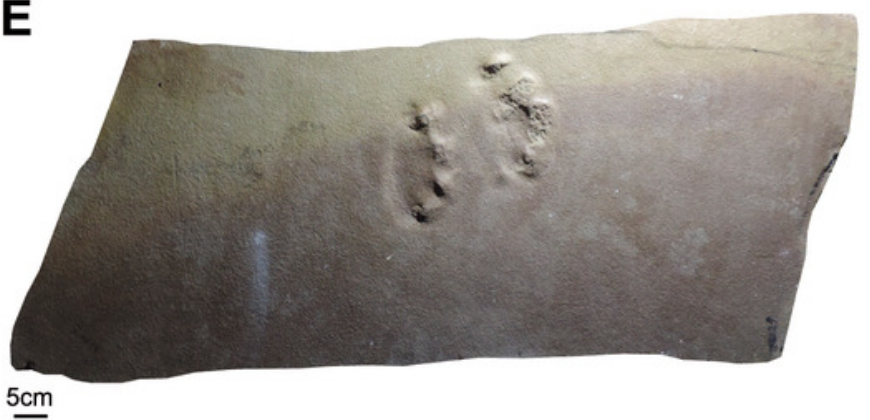

G

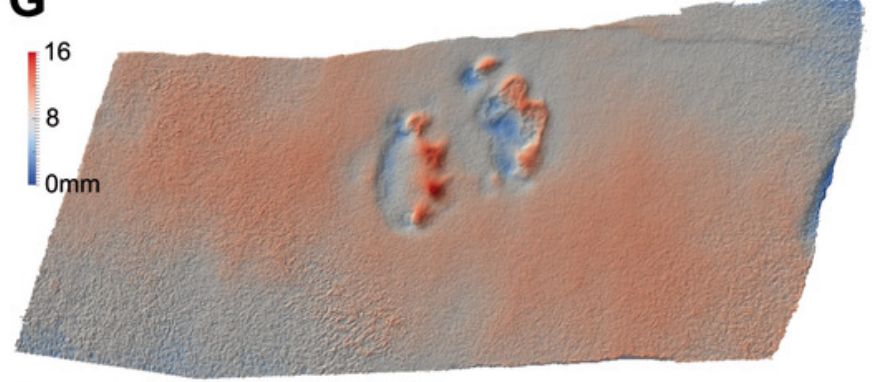

$\stackrel{5 \mathrm{~cm}}{-}$
B

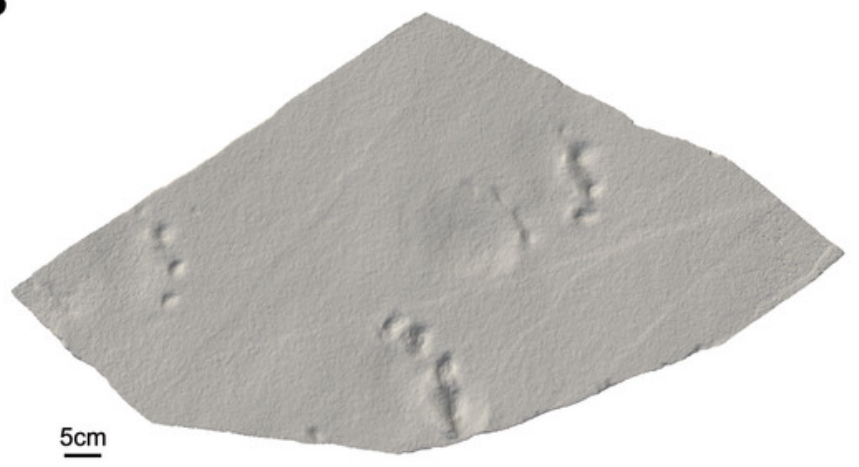

D

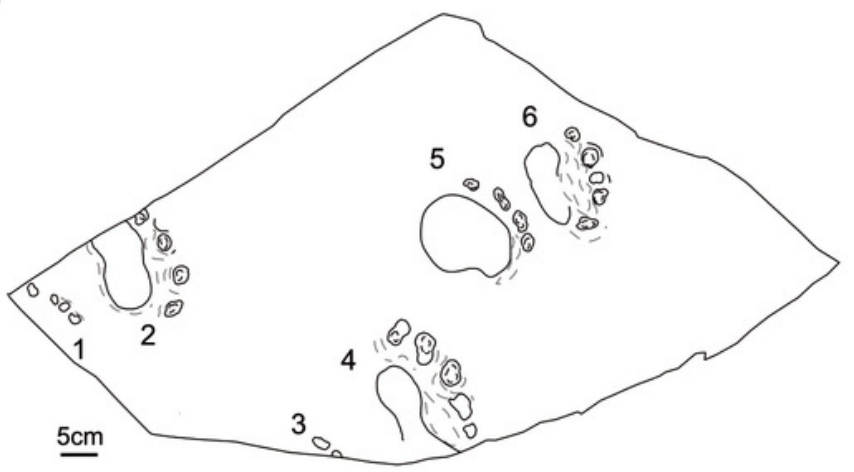

$\mathbf{F}$

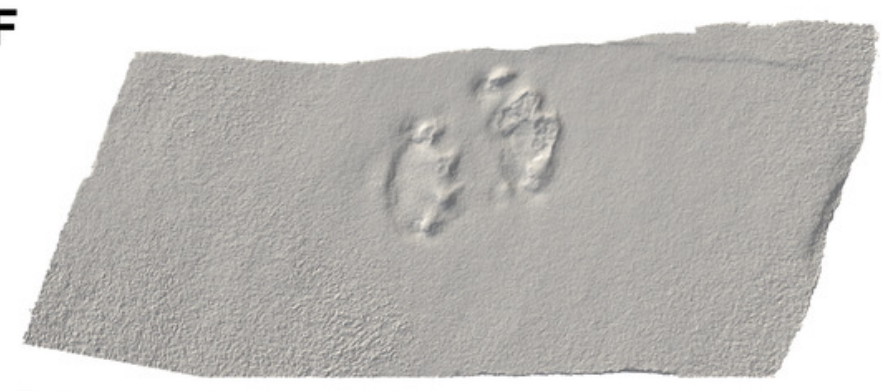

$5 \mathrm{~cm}$

H

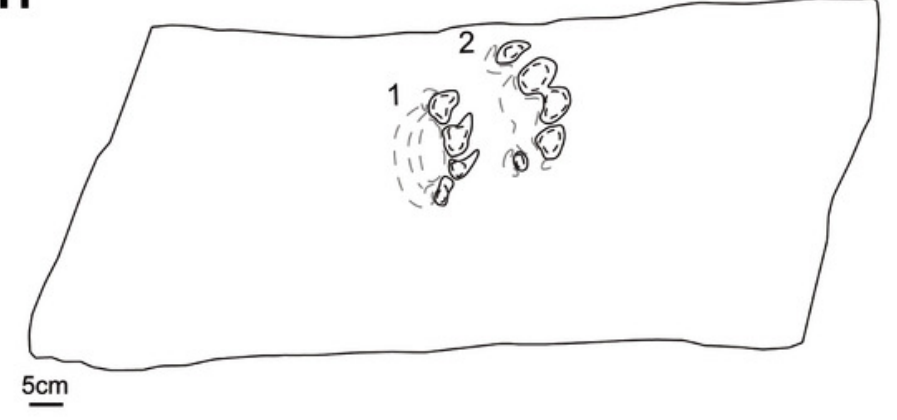




\section{Figure 5}

Photos, three-dimensional models and interpretative drawings of the studied material.

(A) Track-bearing slabs MPCA 27029-3; (B) Solid three-dimensional model of (A); (C) Colour topographic profile and (D) interpretative drawing of (A). (E) Track-bearing slabs MPCA 27029-4; (F) Solid three-dimensional model of (E); (G) Colour topographic profile and (H) interpretative drawing of $(E)$. Note the digit trailing marks slightly affecting the digit traces of footprint 2 in (A)-(D), which are absent in footprints showed in $(E)-(H)$ where digit traces are roughly sub circular in morphology. 

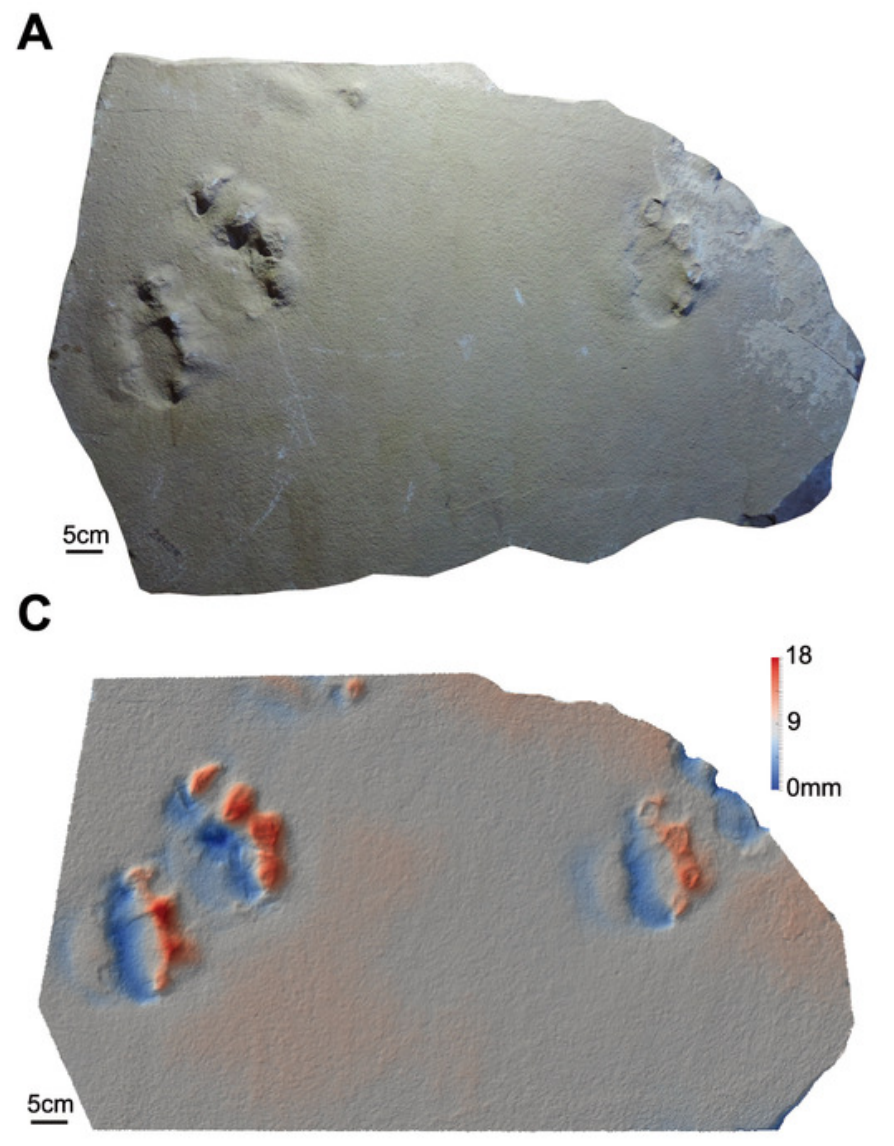

\section{B}
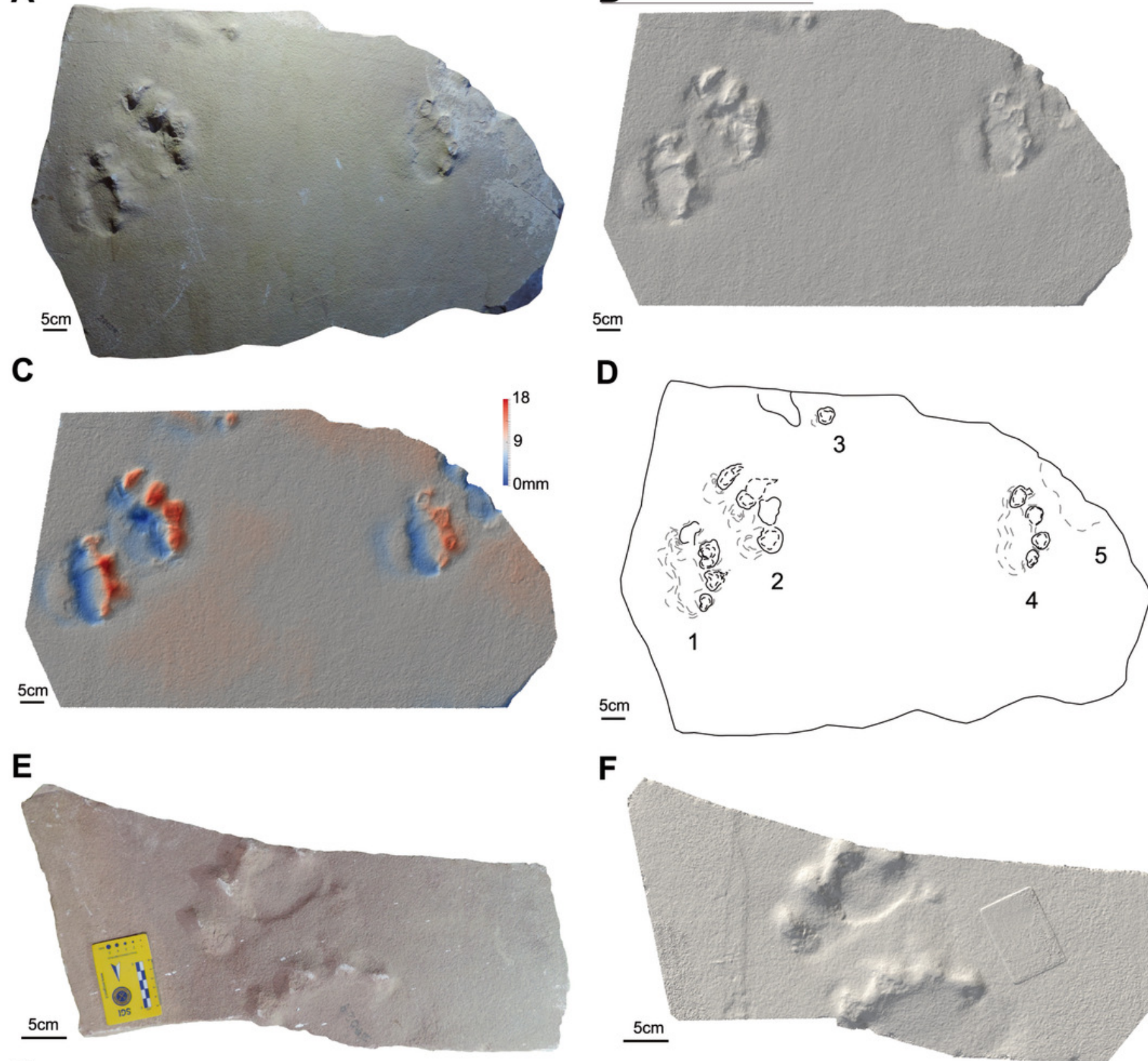

G

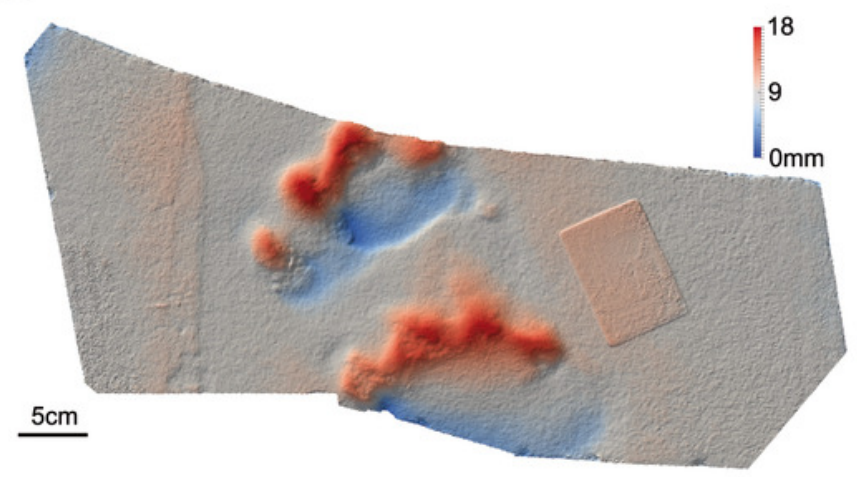

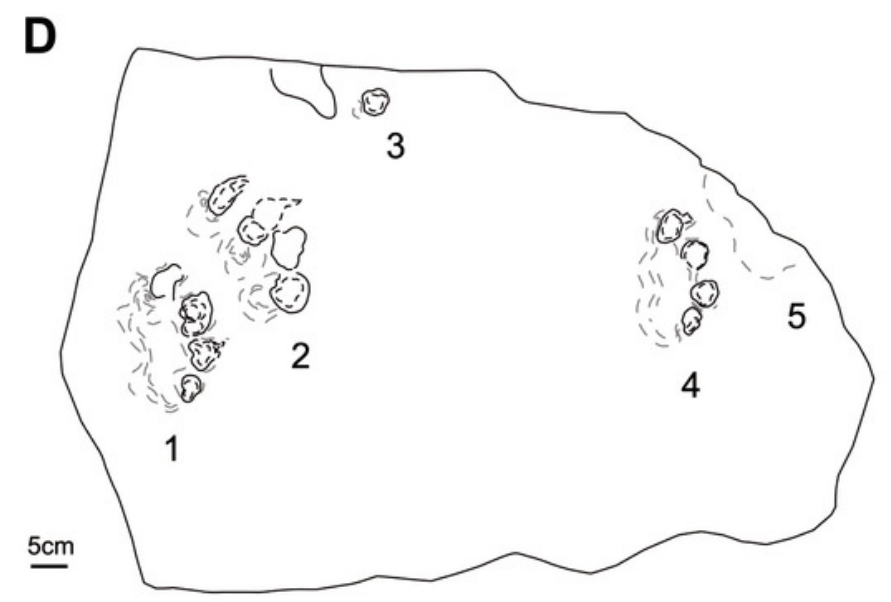

F

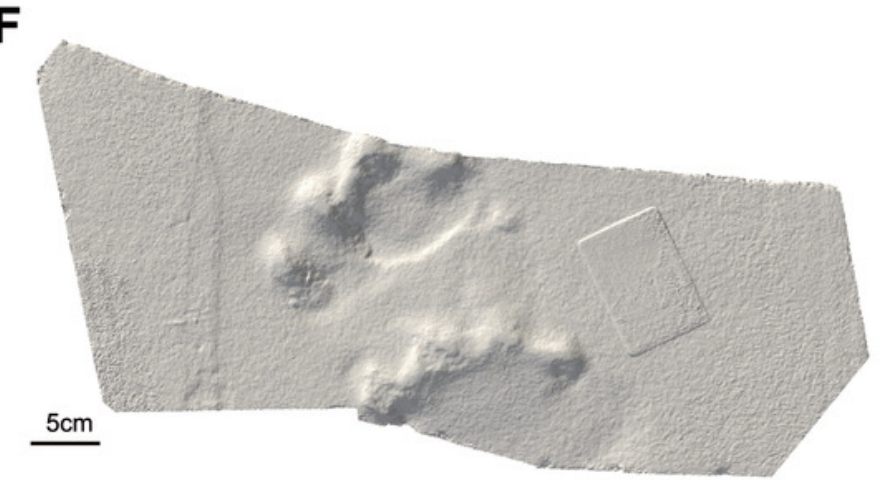

H

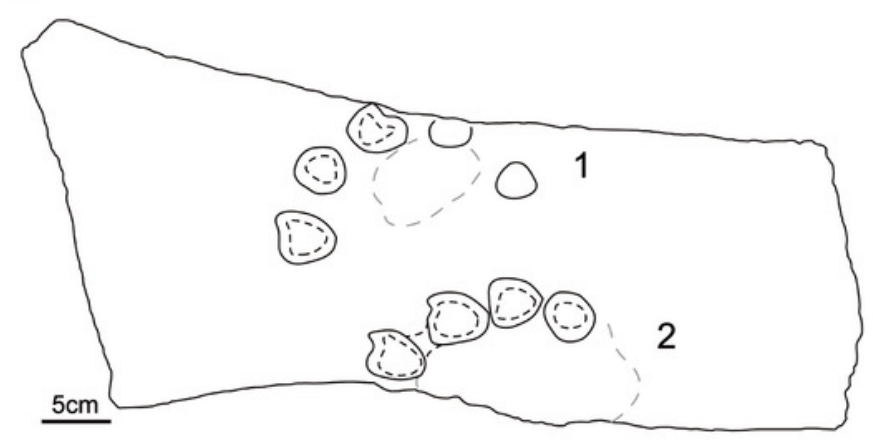




\section{Figure 6}

Photos, three-dimensional models and interpretative drawings of the studied material.

(A) Track-bearing slabs MPCA 27029-5; (B) Solid three-dimensional model of (A); (C) Colour topographic profile and (D) interpretative drawing of (A). (E) Track-bearing slabs MPCA 27029-9; (F) Solid three-dimensional model of (E); (G) Colour topographic profile and (H) interpretative drawing of $(E)$. 


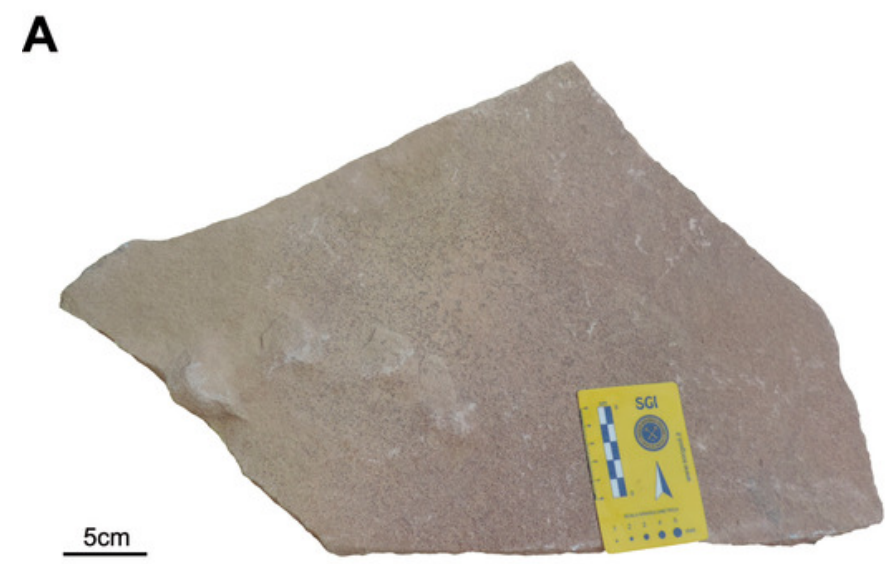

C

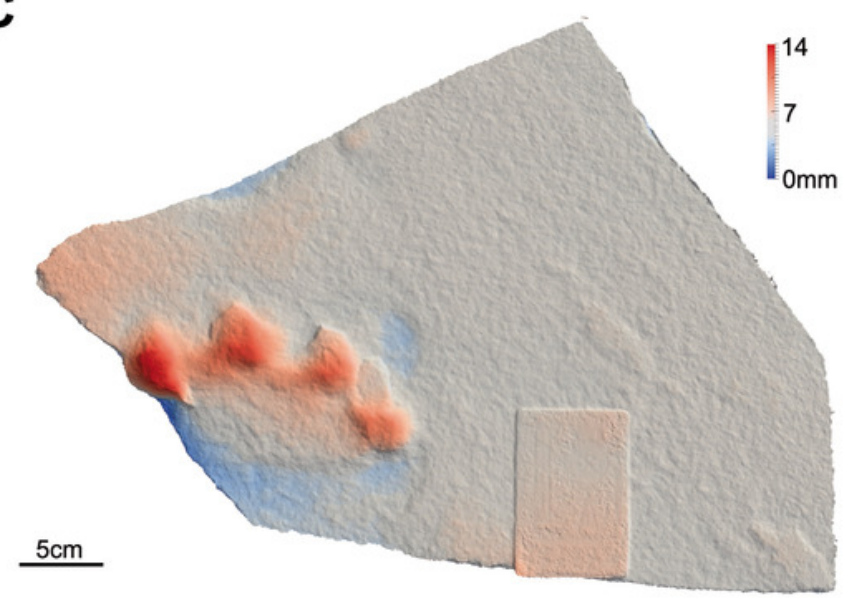

E

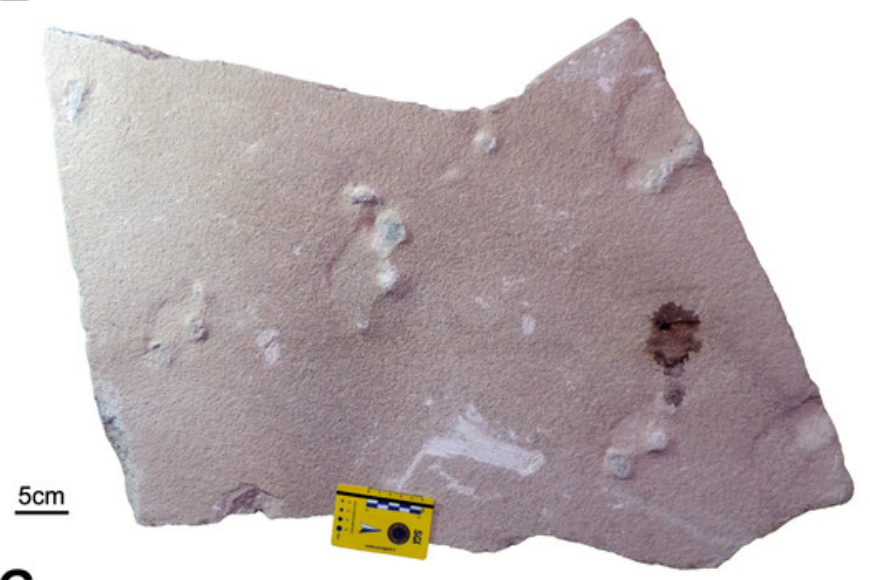

G

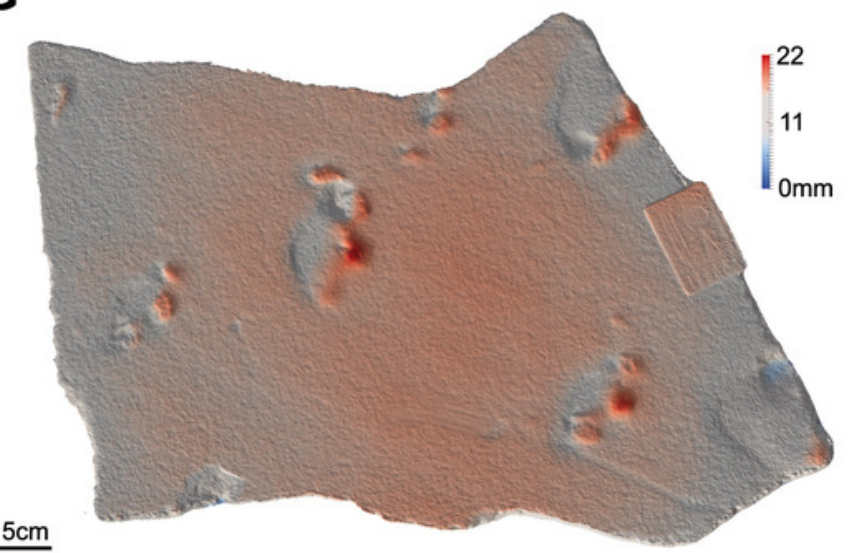

Peer) reviewing PDF | (2018:02:25877:2:0:NEW 4 Jul 2018)
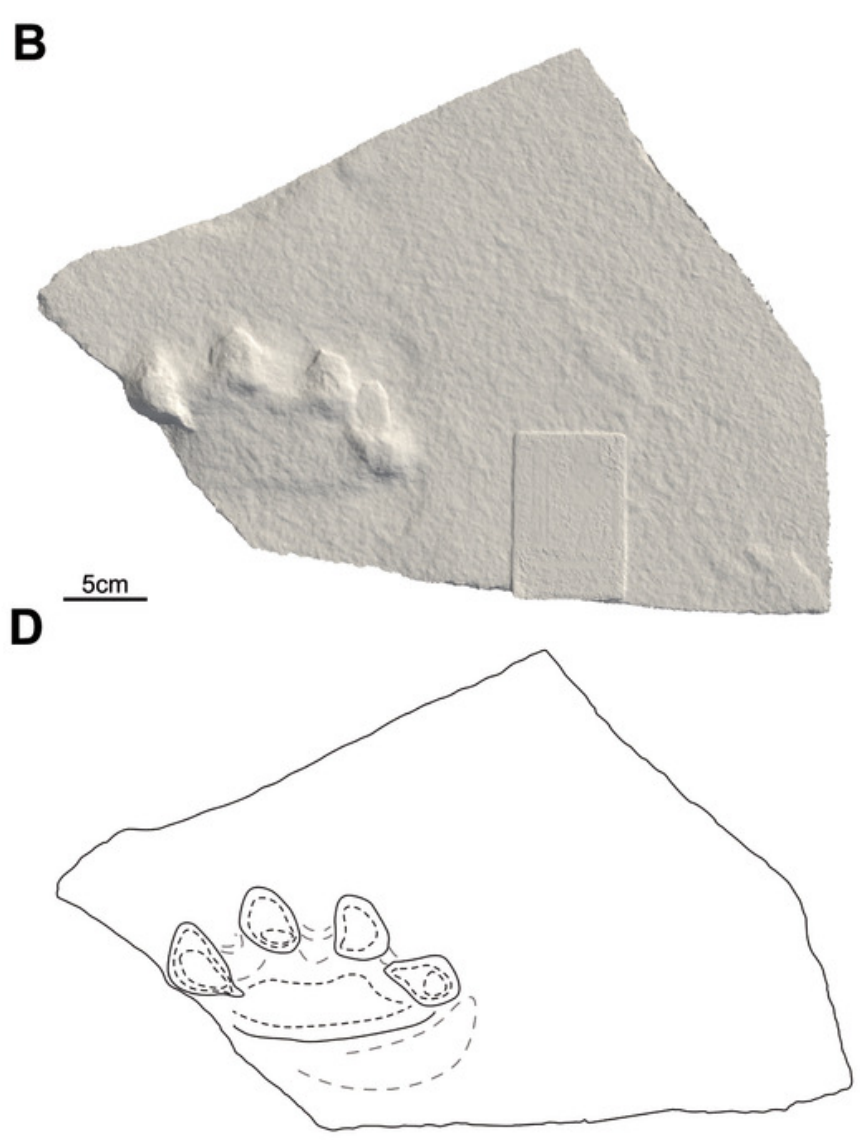

$5 \mathrm{~cm}$

$\mathbf{F}$

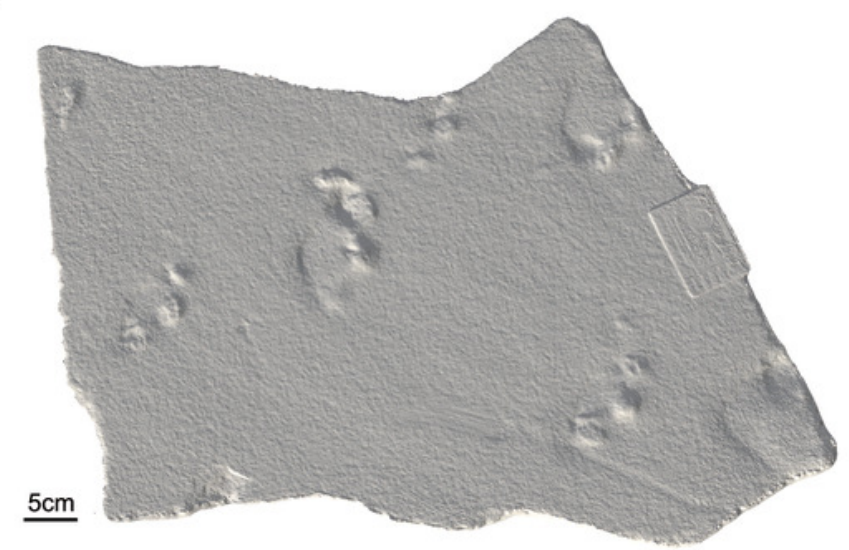

H

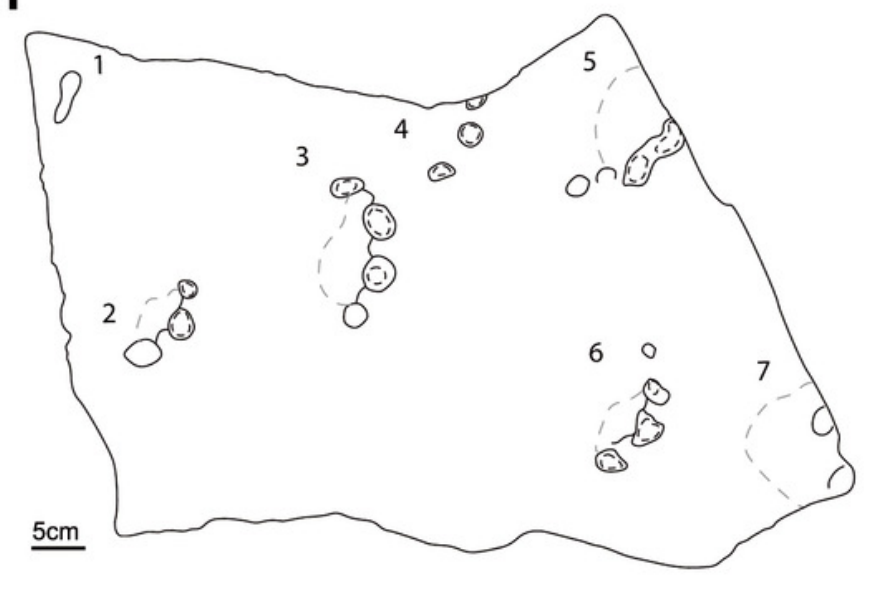




\section{Figure 7}

Photos, three-dimensional models and interpretative drawings of the studied material.

(A) Track-bearing slabs MPCA 27029-16, produced by a juvenile trackmaker; (B) Solid threedimensional model of $(A)$; (C) Colour topographic profile and (D) interpretative drawing of $(A)$. (E) Track-bearing slabs MPCA 27029-21; (F) Solid three-dimensional model of (E); (G) Colour topographic profile and $(\mathrm{H})$ interpretative drawing of $(\mathrm{E})$. The general morphology and structure of footprints 6-10 in (A)-(D), left by a juvenile trackmaker, is identical to that characterizing larger footprints, even when preserved only as digit traces. 
A

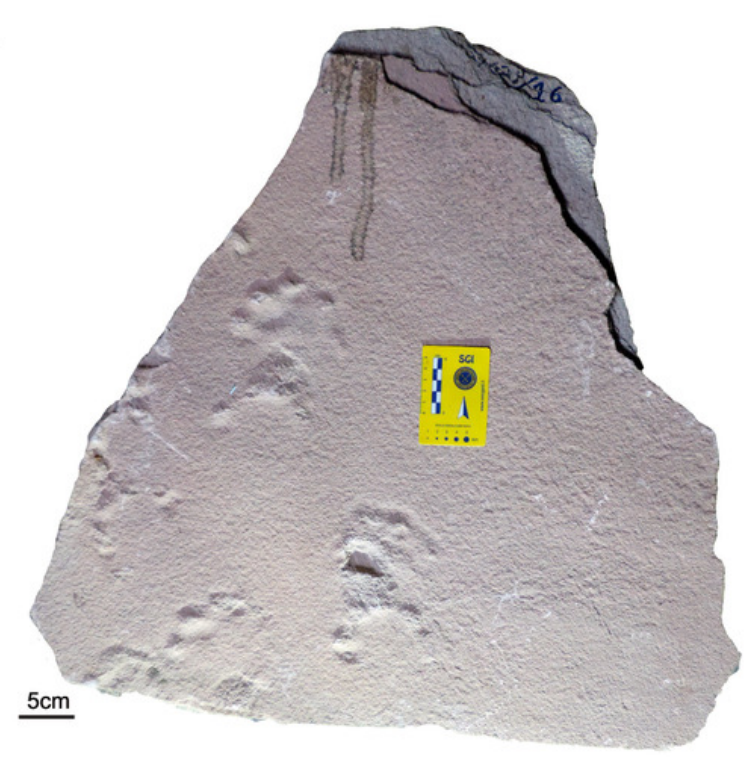

C

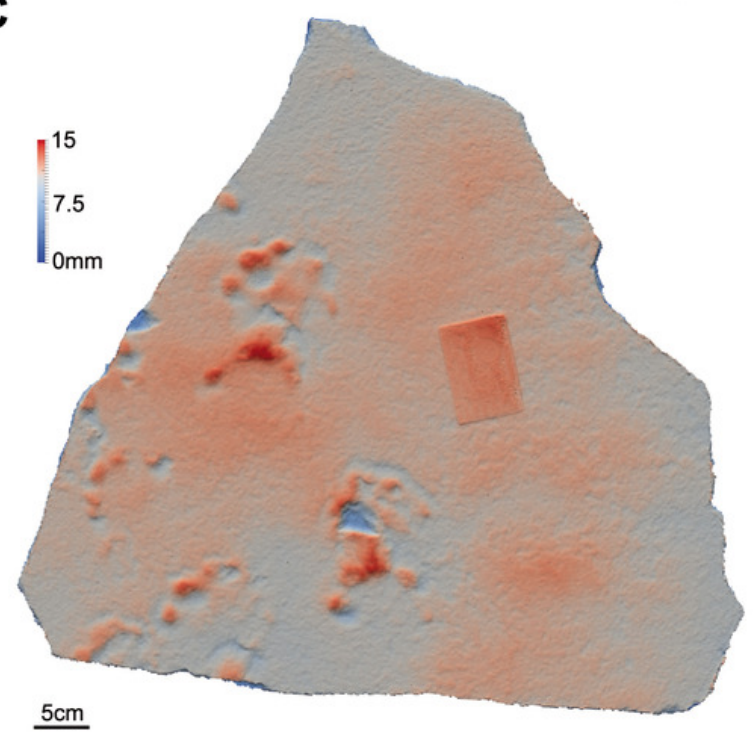

E
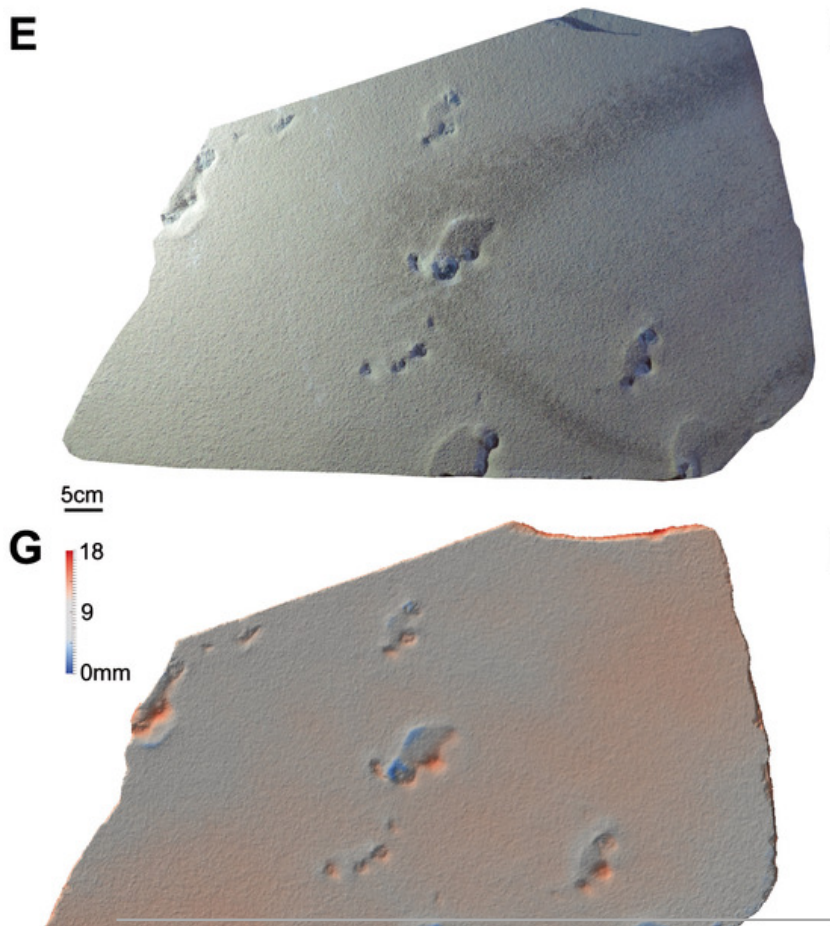

Peer) reviewing PDF | (2018:02:25877:2:0:NEW 4 Jul 2018)
B

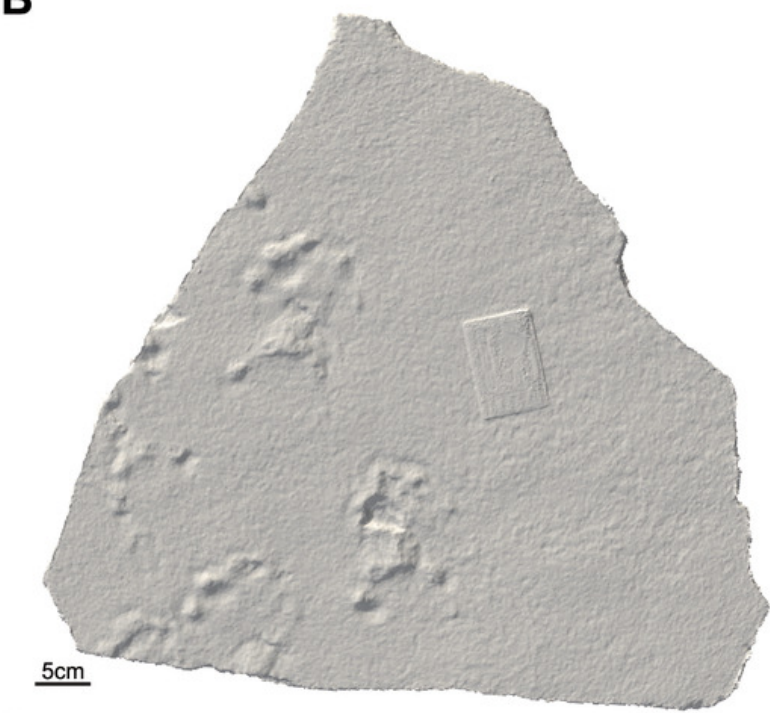

D

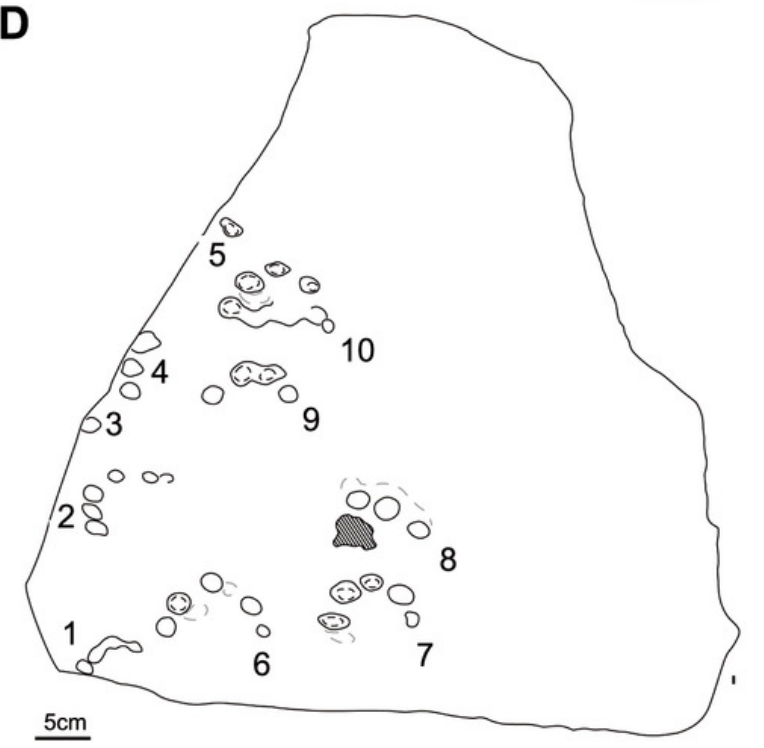

F
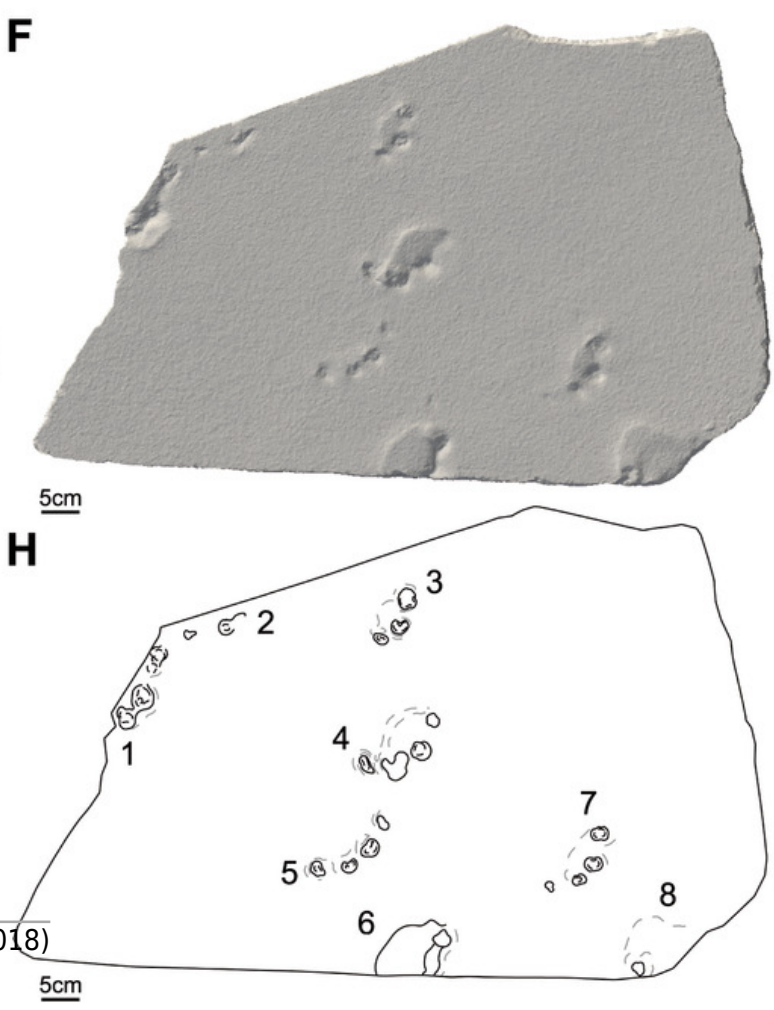


\section{Figure 8}

Photos, three-dimensional models and interpretative drawings of the studied material.

(A) Track-bearing slabs MPCA 27029-33; (B) Solid three-dimensional model of (A); (C) Colour topographic profile and (D) interpretative drawing of (A). (E) Track-bearing slabs MMLM 0751; (F) Solid three-dimensional model of (E); (G) Colour topographic profile and (H) interpretative drawing of $(E)$. In (E)-(H) note the long and sharp digit trailing marks. 
A

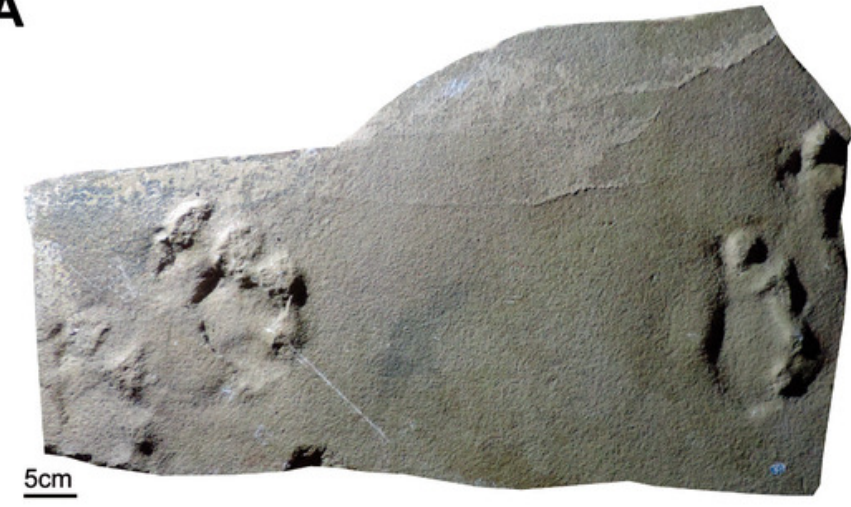

C

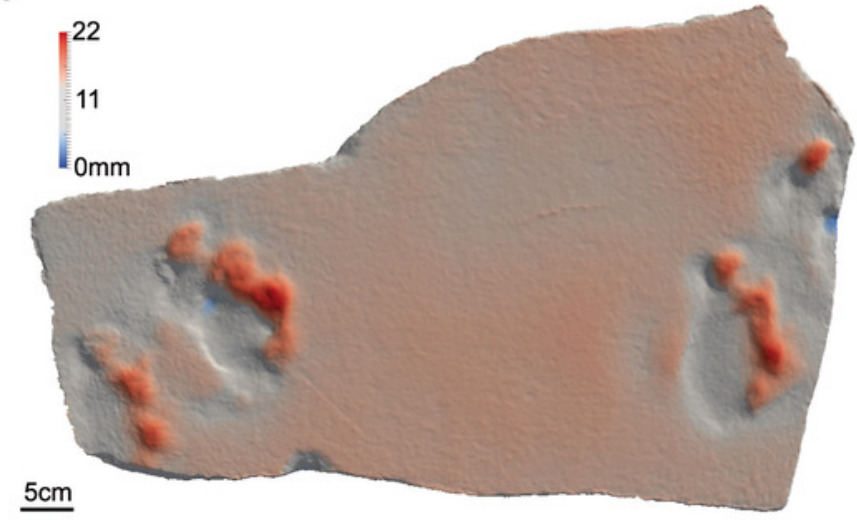

E

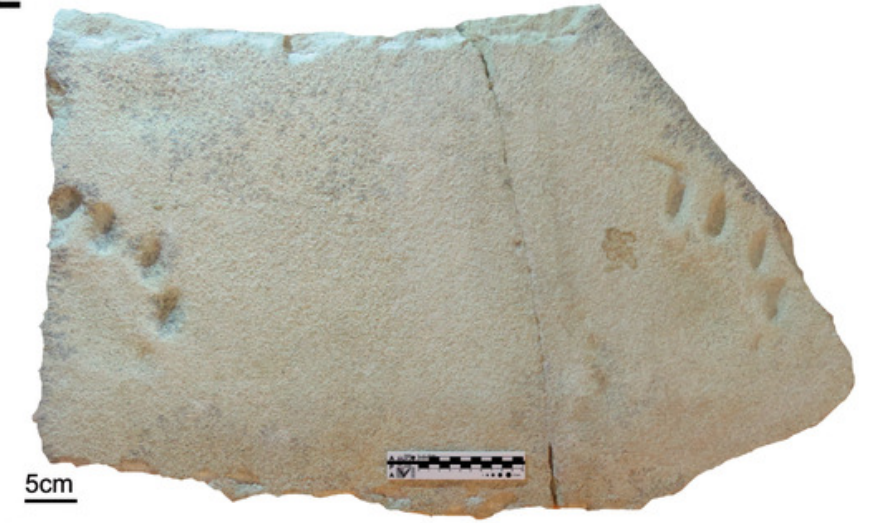

G

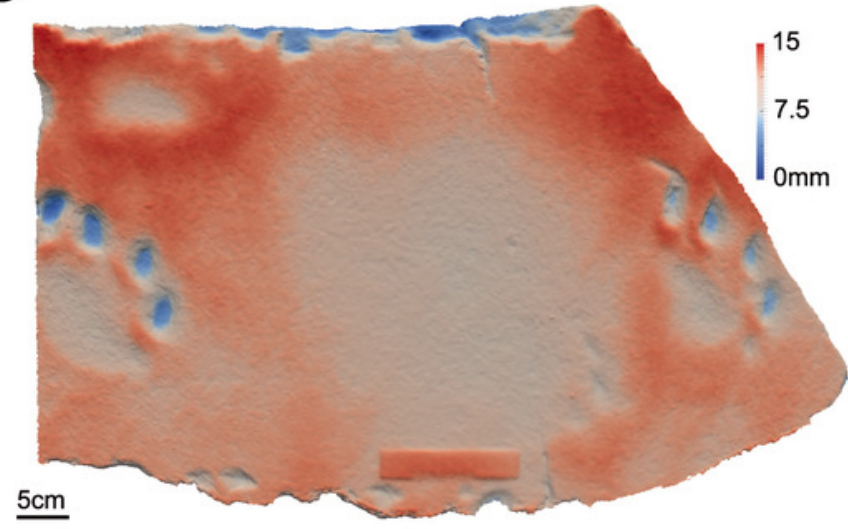

B $\underline{5 \mathrm{~cm}}$

D

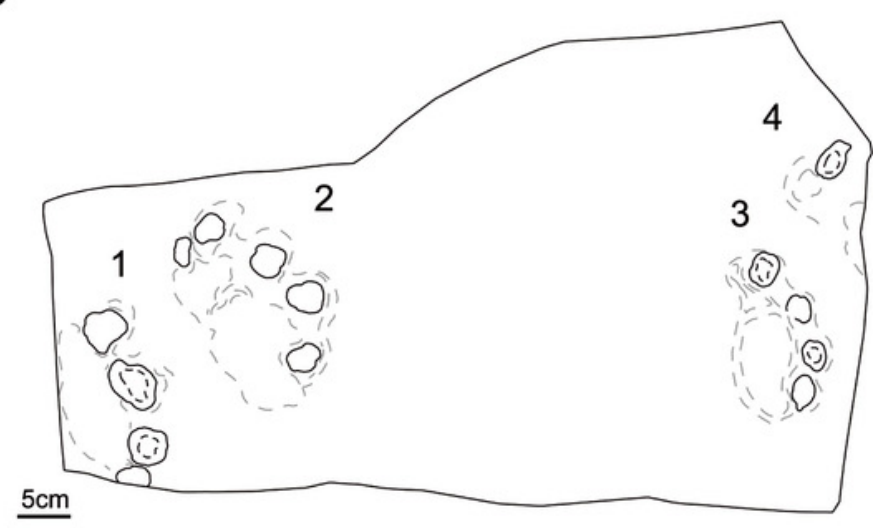

$\mathbf{F}$

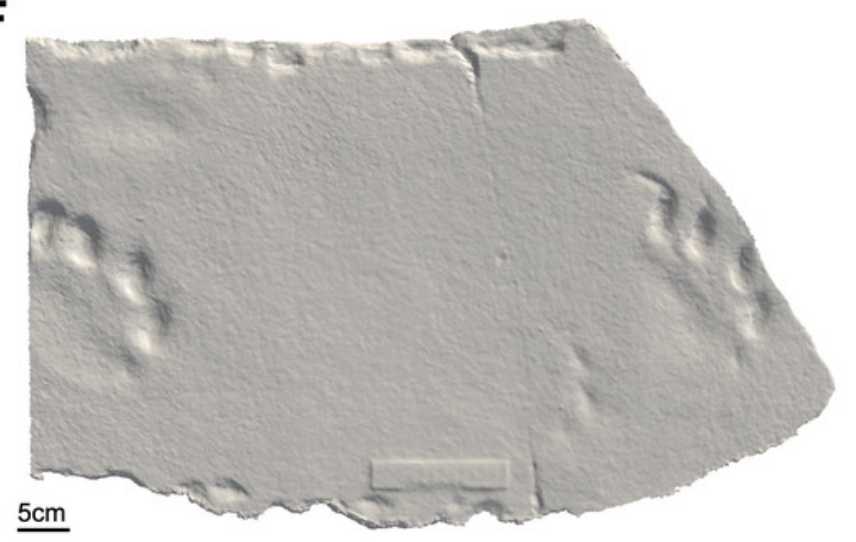

H

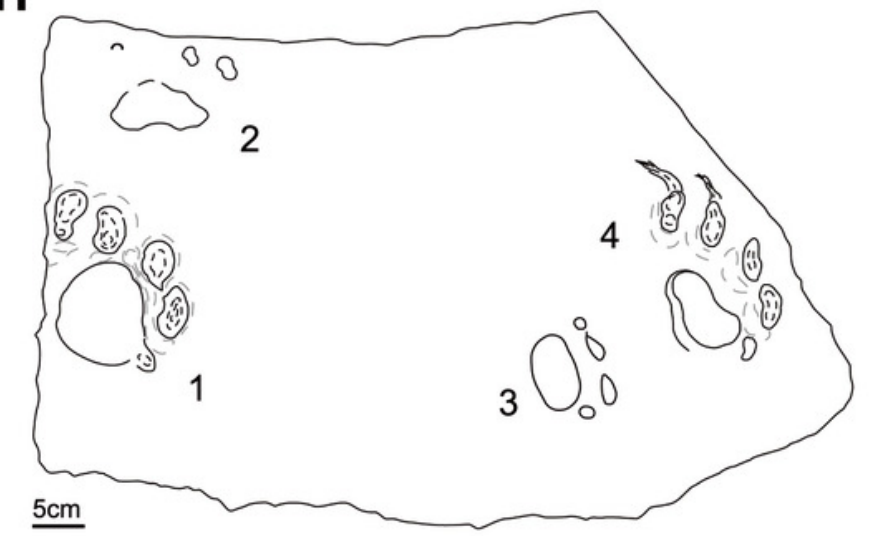




\section{Figure 9}

Photos, three-dimensional models and interpretative drawings of the studied material.

(A) Track-bearing slabs MMLM 1; (B) Solid three-dimensional model of (A); (C) Colour topographic profile and (D) interpretative drawing of (A). (E) Track-bearing slabs MMLM 2; (F) Solid three-dimensional model of $(E) ;(G)$ Colour topographic profile and $(H)$ interpretative drawing of (E). In (A)-(D) note the long and sharp digit trailing marks affecting footprints 2 and 4, resembling those of Figure $8 \mathrm{E}-\mathrm{H}$. 

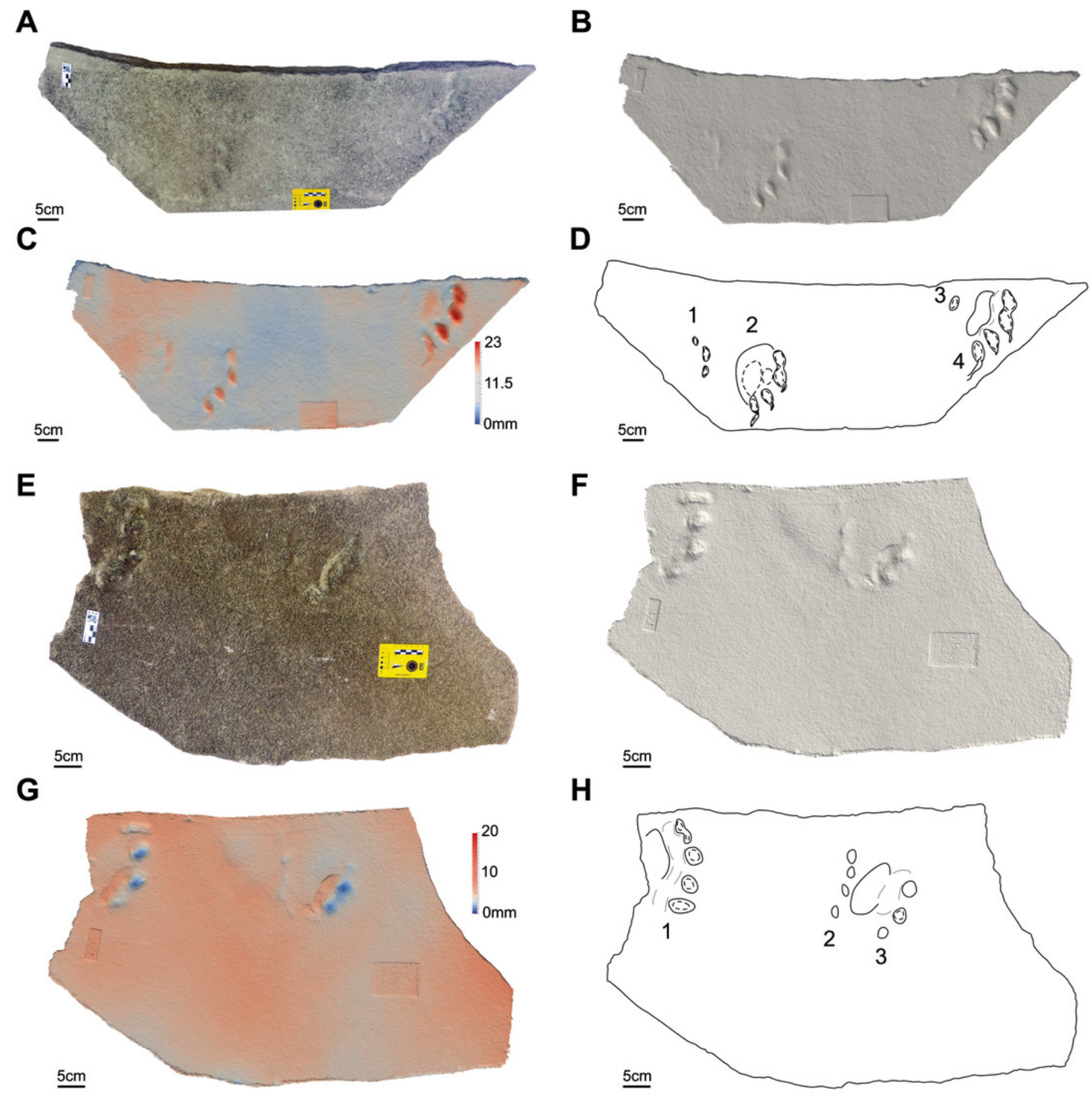


\section{Figure 10}

Morphological and extramorphological features identified on the studied material.

(A) Manus track MPCA $27029 / 2$ and (B) interpretative drawing. (C) Pes track MPCA 27029-1/5 and (D) interpretative drawing. Extramorphological features are in blue and grey, morphological features are in black.
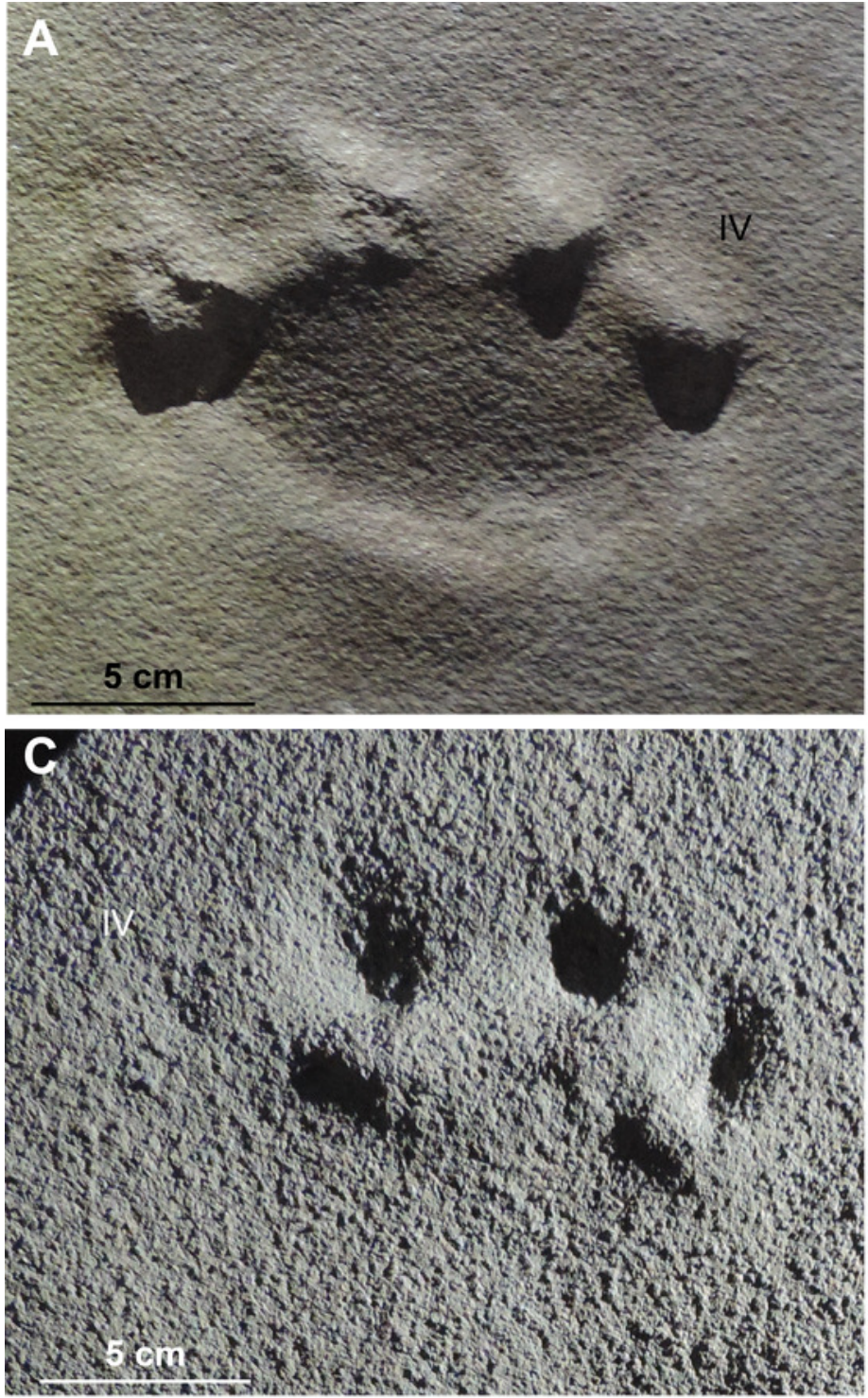
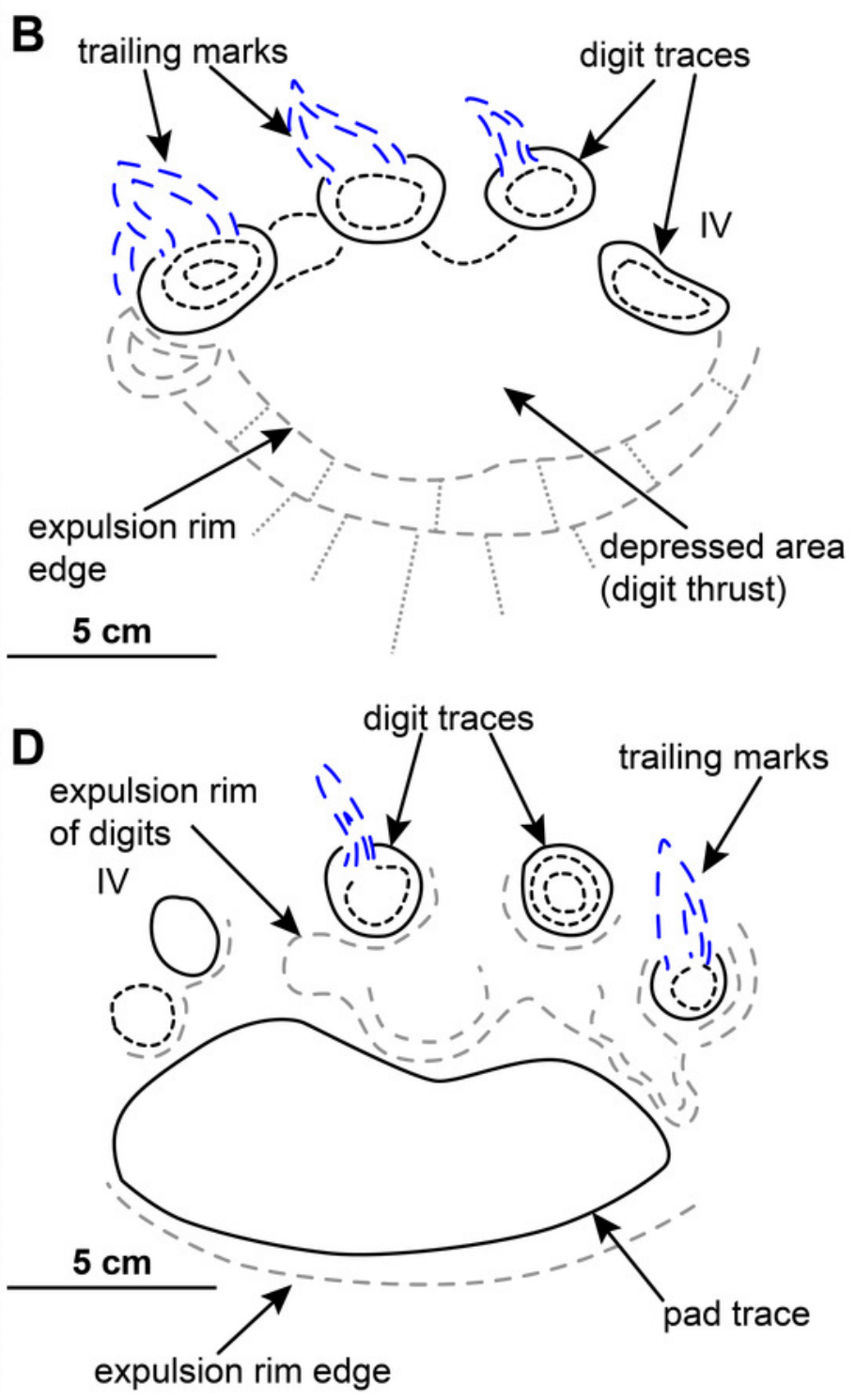


\section{Figure 11}

Limb and autopod posture in the Pentasauropus trackmaker.

Simplified reconstruction of limb posture in back (A) and lateral (B) views. Simplified reconstruction of zeugopodials and hind autopod in lateral (C) and bottom (D) views. In colour the possible extension of the fleshy cushion on which the basipodials rested, ensuring support during locomotion. See the supplementary video to get a more complete view of the reconstruction. Artwork by Fabio Manucci.

A

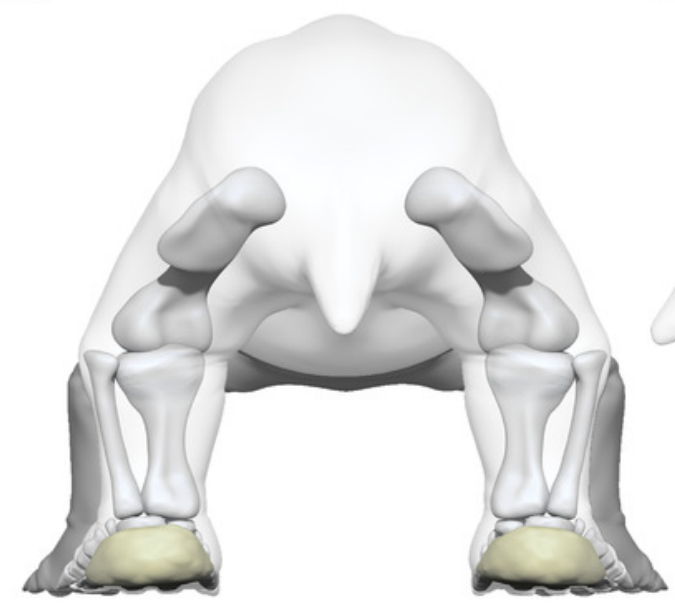

B

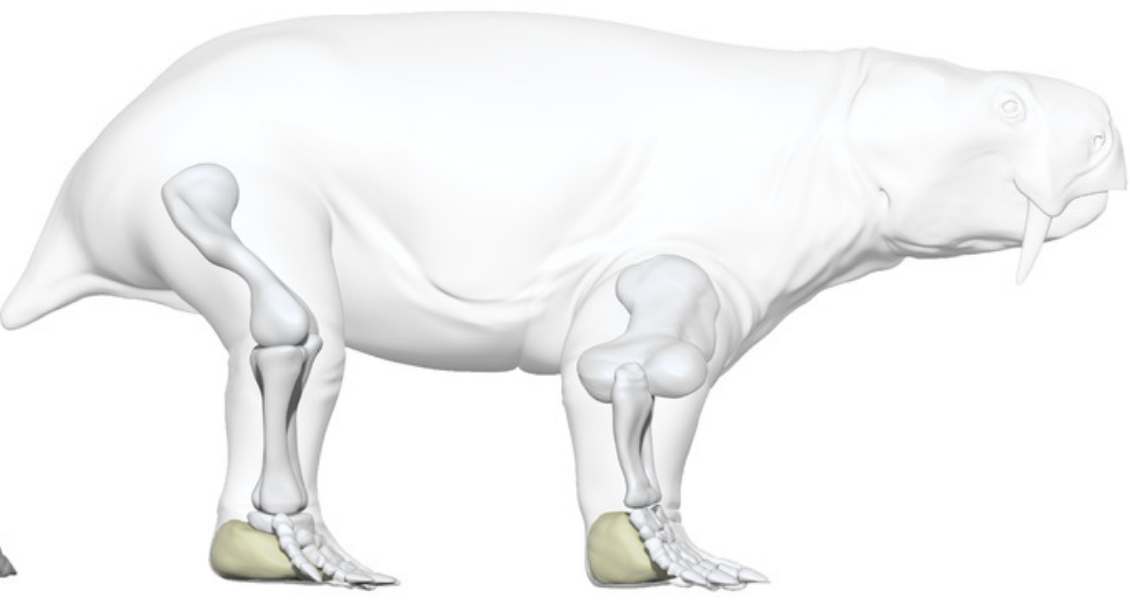

D
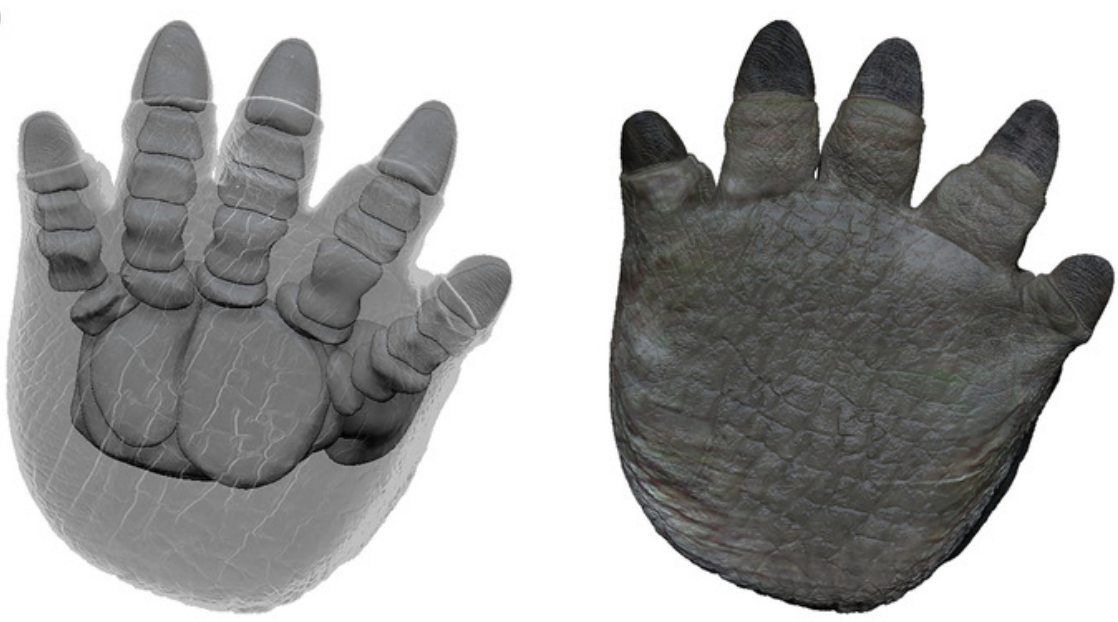


\section{Figure 12}

Speculative in vivo reconstruction (based on Dinodontosaurus) of a kannemeyeriiformes dicynodont, a most probable producer of Pentasauropus tracks.

Reconstruction in back (A) and lateral (B) view of the trackmaker walking in amble gait. See the supplementary video to get a more complete view of the reconstruction. Artwork by Fabio Manucci.
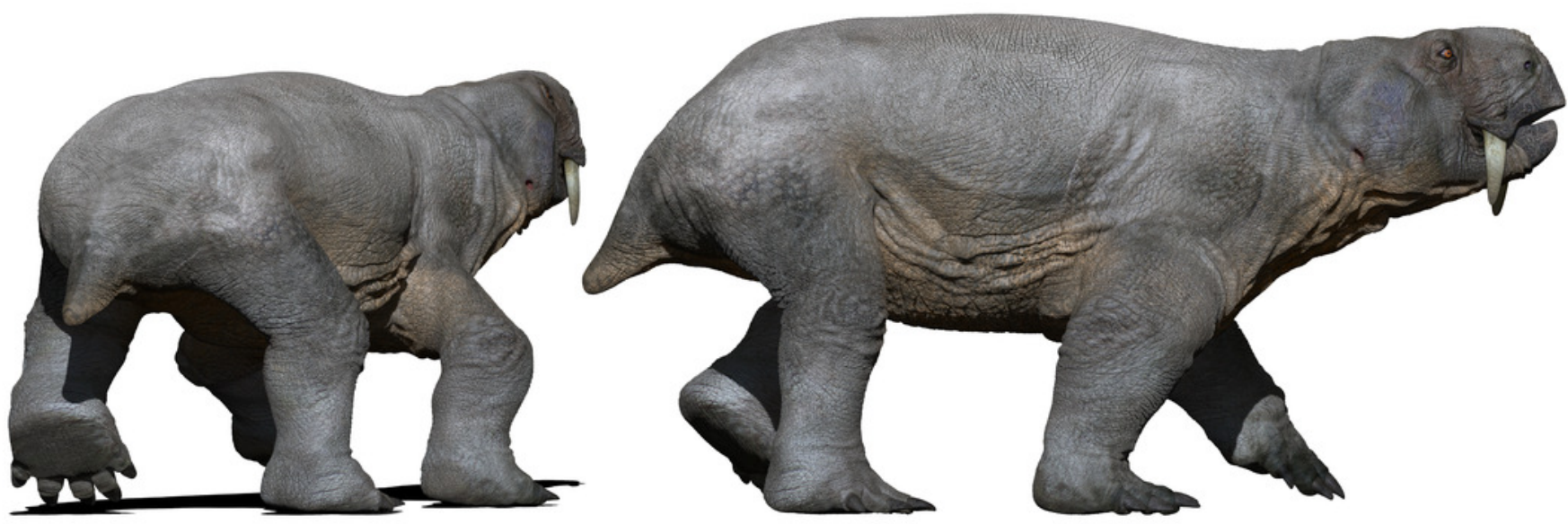

A

B 


\section{Table 1 (on next page)}

Photogrammetric report.

Main processing parameters of the photogrammetric models (from Agisoft Photoscan Professional reports). 


\begin{tabular}{|c|c|c|c|c|c|c|}
\hline 3D Model & $\begin{array}{c}\text { Number } \\
\text { of images }\end{array}$ & $\begin{array}{c}\text { Camera } \\
\text { altitude }(\mathrm{cm})\end{array}$ & $\begin{array}{c}\text { Ground } \\
\text { resolution } \\
(\mathrm{mm} / \mathrm{pix})\end{array}$ & $\begin{array}{l}\text { RMS } \\
\text { reprojection } \\
\text { error }\end{array}$ & $\begin{array}{l}\text { Mean Key } \\
\text { point size } \\
\text { (pix) }\end{array}$ & $\begin{array}{l}\text { Scale bars } \\
\text { total error } \\
\text { (m) }\end{array}$ \\
\hline $\begin{array}{c}\text { MPCA 27029- } \\
1\end{array}$ & 61 & 55 & 0.108 & $\begin{array}{c}0.145637 \\
(0.595447 \text { pix })\end{array}$ & 3.99373 & 0.000211567 \\
\hline $\begin{array}{c}\text { MPCA 27029- } \\
2\end{array}$ & 38 & 49.6 & 0.142 & $\begin{array}{c}0.211741 \\
(0.749639 \text { pix })\end{array}$ & 3.83623 & 0.000120665 \\
\hline $\begin{array}{c}\text { MPCA 27029- } \\
3\end{array}$ & 36 & 63.8 & 0.183 & $\begin{array}{c}0.221627 \\
(0.663238 \text { pix })\end{array}$ & 3.1918 & 0.000101555 \\
\hline $\begin{array}{c}\text { MPCA 27029- } \\
4\end{array}$ & 36 & 26.2 & 0.0753 & $\begin{array}{c}0.225287 \\
(0.695116 \text { pix })\end{array}$ & 3.21872 & 0.000145928 \\
\hline $\begin{array}{c}\text { MPCA 27029- } \\
5\end{array}$ & 25 & 30.2 & 0.0867 & $\begin{array}{c}0.186287 \\
(0.548475 \text { pix })\end{array}$ & 3.41294 & 0.000125956 \\
\hline $\begin{array}{c}\text { MPCA 27029- } \\
9\end{array}$ & 36 & 31.9 & 0.0916 & $\begin{array}{c}0.206052 \\
(0.638116 \text { pix })\end{array}$ & 3.27202 & 0.000154204 \\
\hline $\begin{array}{c}\text { MPCA 27029- } \\
16\end{array}$ & 30 & 52.3 & 0.13 & $\begin{array}{c}0.254353 \\
(0.874324 \text { pix })\end{array}$ & 3.64063 & 0.000179922 \\
\hline $\begin{array}{c}\text { MPCA 27029- } \\
21\end{array}$ & 59 & 47.3 & 0.127 & $\begin{array}{c}0.273984 \\
(0.529254 \text { pix })\end{array}$ & 2.28824 & 0.000184177 \\
\hline $\begin{array}{c}\text { MPCA 27029- } \\
33\end{array}$ & 74 & 50.2 & 0.144 & $\begin{array}{c}0.25616 \\
(0.993387 \text { pix })\end{array}$ & 3.90857 & 0.000121254 \\
\hline MMLM 075-1 & 54 & 37.8 & 0.0898 & $\begin{array}{c}0.196238 \\
(0.739726 \text { pix })\end{array}$ & 3.75732 & 0.000118491 \\
\hline MMLM 1 & 77 & 42.5 & 0.101 & $\begin{array}{c}0.222075 \\
(0.673395 \text { pix })\end{array}$ & 3.09592 & 0.00332392 \\
\hline MMLM 2 & 52 & 33 & 0.0949 & $\begin{array}{c}0.234591 \\
(0.852769 \text { pix })\end{array}$ & 3.78559 & $5.99994 \mathrm{e}-05$ \\
\hline
\end{tabular}




\section{Table 2 (on next page)}

Mean measurements (in $\mathrm{cm}$ ) of track and trackway parameters.

ETW, external trackway width; FI, footprint length; Fw, footprint width; GAD, gleno-acetabular distance: (a), 'primitive' alternate pace (the trunk length of the producer is underestimated); (b), alternate pace; (c), amble (a, b, c, considering primary overlap sensu Leonardi, 1987); ITW, internal trackway width; Mpa, manus pace angulation; Mpl, manus pace length; Msl, manus stride length; Ppa, pes pace angulation; Ppl, pes pace length; Psl, pes stride length; PsI/GAD, pes stride length/gleno-acetabular distance ratio; ETW/SL, external trackway width/stride length ratio. 


\begin{tabular}{|c|c|c|c|c|c|c|c|c|c|c|c|c|c|}
\hline Specimen & Fl & $\mathbf{F w}$ & Mpl & Ppl & Мра & Ppa & Msl & Psl & $\begin{array}{l}\text { ET } \\
\mathbf{W}\end{array}$ & ITW & ETW/SL & GAD & $\begin{array}{c}\text { Psl/GA } \\
\text { D }\end{array}$ \\
\hline $\begin{array}{c}\text { MPCA } \\
27029-1\end{array}$ & $\begin{array}{c}10.6 \\
12.8 \\
8.9\end{array}$ & $\begin{array}{l}10.3 \\
12.2\end{array}$ & $\begin{array}{l}42.2 \\
33.3\end{array}$ & $\begin{array}{l}41.7 \\
40.5\end{array}$ & $101^{\circ}$ & $99^{\circ}$ & 59.5 & 62.4 & 50.0 & 3.65 & 0.82 & $\begin{array}{l}46.2(\mathrm{a}) \\
47.8(\mathrm{~b}) \\
91.6(\mathrm{c})\end{array}$ & 1.01 \\
\hline $\begin{array}{c}\text { MPCA } \\
27029-2\end{array}$ & / & $\begin{array}{l}15.7 \\
13.5\end{array}$ & / & / & / & / & / & / & l & l & / & / & I \\
\hline $\begin{array}{c}\text { MPCA } \\
27029-3\end{array}$ & / & $\begin{array}{l}12.7 \\
14.7\end{array}$ & / & I & I & / & / & 63.5 & I & I & I & I & I \\
\hline $\begin{array}{c}\text { MPCA } \\
27029-4\end{array}$ & / & $\begin{array}{l}12.6 \\
13.3\end{array}$ & / & / & / & / & I & / & l & l & l & I & I \\
\hline $\begin{array}{c}\text { MPCA } \\
27029-5\end{array}$ & 6.6 & 11.6 & / & I & I & / & I & / & l & I & l & l & I \\
\hline $\begin{array}{c}\text { MPCA } \\
27029-9\end{array}$ & / & $\begin{array}{c}7.4 \\
10.9\end{array}$ & 28.5 & $\begin{array}{l}37.0 \\
32.5\end{array}$ & / & $81^{\circ}$ & I & 45.5 & 36 & 7.36 & 0.79 & $\begin{array}{l}40.0(\mathrm{a}) \\
46.9 \text { (b) } \\
63.1(\mathrm{c})\end{array}$ & 0.91 \\
\hline $\begin{array}{c}\text { MPCA } \\
27029-16\end{array}$ & 5.6 & $\begin{array}{l}8.1 \\
7.1\end{array}$ & $\begin{array}{l}21.0 \\
15.0\end{array}$ & 22.5 & $100^{\circ}$ & / & 28.5 & / & 23.0 & 4.40 & 0.81 & $\begin{array}{l}26.0(\mathrm{a}) \\
33.1(\mathrm{~b}) \\
37.4(\mathrm{c})\end{array}$ & / \\
\hline $\begin{array}{c}\text { MPCA } \\
27029-21\end{array}$ & I & 10.7 & / & $\begin{array}{l}37.0 \\
34.0 \\
34.5\end{array}$ & / & $70^{\circ}$ & / & $\begin{array}{c}37.5 \\
41\end{array}$ & 38.5 & 5.85 & 1.03 & I & / \\
\hline $\begin{array}{c}\text { MPCA } \\
27029-33\end{array}$ & I & $\begin{array}{l}15.4 \\
12.8\end{array}$ & / & l & I & / & I & 63.5 & I & I & l & l & / \\
\hline $\begin{array}{c}\text { MMLM } \\
075-1\end{array}$ & $\begin{array}{l}10.2 \\
11.8\end{array}$ & $\begin{array}{c}13.6 \\
9.8\end{array}$ & / & / & / & / & l & 57.3 & l & l & / & I & / \\
\hline MMLM 1 & $\begin{array}{l}10.2 \\
10.9\end{array}$ & $\begin{array}{c}13.5 \\
14\end{array}$ & I & I & l & / & 52.0 & / & l & l & / & I & / \\
\hline MMLM 2 & / & $\begin{array}{l}12.2 \\
11.4\end{array}$ & / & / & / & / & 40.5 & / & / & l & / & I & / \\
\hline
\end{tabular}




\section{Table 3(on next page)}

Sole pad-ungual trace distance.

Distance (in $\mathrm{cm}$ ) between the distal margin of the sole pad trace and the proximal margin of the digit traces in complete Pentasauropus footprints. The measurements most likely indicate a raised and inclined position of the metapodial elements of fore and hind foot in the Pentasauropus trackmaker. 


\begin{tabular}{|c|c|c|c|c|c|}
\hline \multicolumn{6}{|c|}{ MPCA 27029-1 } \\
\hline & Digit I & Digit II & Digit III & Digit IV & Digit V \\
\hline Footprint 2 & 1.35 & 1.41 & 1.84 & 1.22 & l \\
\hline Footprint 4 & 1.68 & 1.66 & 1.84 & 1.91 & / \\
\hline Footprint 5 & / & 1.26 & 1.45 & 1.52 & 1.20 \\
\hline Footprint 6 & 1.2 & 1.25 & 2.18 & 2.24 & 1.33 \\
\hline \multicolumn{6}{|c|}{ MPCA 27029-5 } \\
\hline & Digit I & Digit II & Digit III & Digit IV & Digit V \\
\hline Footprint 1 & l & 0 & 0.96 & 1.13 & 0.4 \\
\hline \multicolumn{6}{|c|}{ MPCA 27029-16 } \\
\hline & Digit I & Digit II & Digit III & Digit IV & Digit V \\
\hline Footprint 10 & 0.92 & 0.9 & 1.1 & 0.94 & 0.79 \\
\hline \multicolumn{6}{|c|}{ MMLM 075-1 } \\
\hline & Digit I & Digit II & Digit III & Digit IV & Digit V \\
\hline Footprint 1 & 1.65 & 2.09 & 2.94 & 2.56 & 1.45 \\
\hline Footprint 3 & / & 1.41 & 1.68 & 2.19 & 1.63 \\
\hline Footprint 4 & 1.95 & 2.25 & 2.45 & 2.25 & 1.58 \\
\hline \multicolumn{6}{|c|}{ MMLM 1} \\
\hline & Digit I & Digit II & Digit III & Digit IV & Digit V \\
\hline Footprint 2 & 1.88 & 2.53 & 2.73 & 2.25 & l \\
\hline Footprint 4 & 1.59 & 1.86 & 2.25 & 2.12 & l \\
\hline \multicolumn{6}{|c|}{ MMLM 2} \\
\hline & Digit I & Digit II & Digit III & Digit IV & Digit V \\
\hline Footprint 1 & 1.66 & 2.37 & 2.02 & 2.27 & / \\
\hline
\end{tabular}

